OPEN ACCESS

Citation: Marta D'Andrea (2021) Ebla between the Early and Middle Bronze Ages: A Précis (and Some New Data). Asia Anteriore Antica. Journal of Ancient Near Eastern Cultures 3: 3-41. doi: 10.36253/asiana-1199

Copyright: ( 2021 Marta D’Andrea. This is an open access, peer-reviewed article published by Firenze University Press (http://www.fupress.com/asiana) and distributed under the terms of the Creative Commons Attribution License, which permits unrestricted use, distribution, and reproduction in any medium, provided the original author and source are credited.

Data Availability Statement: All relevant data are within the paper and its Supporting Information files.

Competing Interests: The Author(s) declare(s) no conflict of interest.

\section{Ebla between the Early and Middle Bronze Ages: A Précis (and Some New Data)}

\author{
MARTA D'Andrea \\ Sapienza Università di Roma, Dipartimento di Scienze dell'Antichità \\ marta.dandrea@uniromal.it
}

\begin{abstract}
The discoveries of the 2004-2008 excavations at Tell Mardikh, ancient Ebla, in north-western Syria, and the following processing of the archaeological record have allowed for a re-examination the site's trajectory between Early Bronze IVB and Middle Bronze I. Not only it was possible to gain a clearer picture of the site's trajectory during Early Bronze IVB, the phase following the demise of Ebla's Early Bronze IVA kingdom, but also to re-investigate how the site transitioned from the Early to the Middle Bronze Age at a deeper chronological scale, which was hampered before by the lack of sufficient stratified data. Moving from these insights, this paper offers a summary of the state of research on Ebla between the Early and the Middle Bronze Ages and proposes some ideas concerning this critical nexus in the site's development. Moreover, unpublished stratified ceramic data are presented and examined that might allow current synchronisms between Ebla, the Middle Euphrates, and the Syrian Jazirah between the late 3rd and the early 2 nd millennium BC to be re-considered, and to shed light on the site's participation and role in region-wide processes that were taking place between the 3rd and the 2nd millennium BC. This way, this crucial connection in the developmental trajectory of Ebla and in the study of ancient Syria will be re-analysed offering insights into archaeology, chronology, and history.
\end{abstract}

Keywords. Ebla, Northern Levant, Upper Mesopotamia, Early-Middle Bronze transition, Ur III period, chronology, synchronization, pottery, Early Khabur Ware, Amorites.

\section{INTRODUCTION}

Traditionally, the passage from the Early to the Middle Bronze Age in Syria relates to urban regeneration between the $3^{\text {rd }}$ and the $2^{\text {nd }}$ millennium $\mathrm{BC}$ and the emergence of Amorite identities in the region. The investigation of the processes through which Ebla, the Bronze Age city corresponding to present-day Tell Mardikh (Fig. 1), in north-western inland Syria, transitioned from the Early to the Middle Bronze Age is a long-standing 
question, which many scholars have tried to answer during the past decades. However, the examination of this matter at a deeper chronological scale was hampered by the lack of sufficient stratified data to investigate the period between the end of Ebla's territorial state, which flourished in the 24th century BC, and the establishment of the 'Amorite' city at the onset of the $2^{\text {nd }}$ millennium BC. Initially, the question has been framed within the conceptual scaffolding of the 'dark age' at the end of the $3^{\text {rd }}$ millennium $\mathrm{BC}$ and of the regeneration of complex societies at the dawn of the $2^{\text {nd }}$ millennium BC (Akkermans, Schwartz 2003: 282-284). The first is largely superseded now, although it still resonates in a few recent works (see infra), the second is currently subject to a historical reevaluation in the light of emerging greater continuity between the later Early Bronze Age and the earlier Middle Bronze Age traditions in western inland Syria (Morandi Bonacossi 2014: 416-419). From the standpoint of Ebla, the excavations carried out by the Italian team of Sapienza University of Rome in the Lower Town south-east from 2004 to 2007 uncovered, for the first time at this site, a long occupational sequence (Fig. 2) spanning from Early Bronze IVA (EB IVA) to Middle Bronze II (MB II), and, for what concerns this article, a multi-phased Early Bronze IVB occupation, nestled between the remains of the Early Bronze IVA and the Middle Bronze I (MB I) strata, and more stratified evidence of Early Bronze IVB (EB IVB) was found on the Acropolis in 2008 (Fig. 3) (Matthiae 2006a: 470-475; 2007: 493-512; 2009a: 773-777; 2010: 191-208, 390, 395-398; 2020: 95-105; 2021: 143-154, 299-300, 303-306; D’Andrea 2014-2015; 2016a; 2018; 2020a).

This discovery has allowed us to piece together the scattered evidence for the EB IVB occupation previously uncovered at the site and to try and re-evaluate it chronologically and historically. In this article, we summarize the state of research on Ebla's developments between the Early and the Middle Bronze Ages and present unpublished stratified ceramic data that might allow us to re-examine certain proposals of interregional synchronisms between Ebla, the Middle Euphrates, and the Syrian Jazirah, namely the hypothesis that the Ur III period may be contemporary with the Middle Bronze I (MB I) stratum Mardikh IIIA, rather than with the later part of the EB IVB stratum Mardikh IIB2 (see, e.g., Porter 2007: chart 1; Pruß 2007: 485-486; Pfälzner 2017: 172-173, 175 and infra). We will use the discoveries made at Tell Mardikh from 2004 to 2008 and the results of the ensuing postexcavation study of the archaeological record to discuss how these data may change the way we understand the crucial nexus between the Early and the Middle Bronze Ages at Ebla and may shed light on the site's participation and role in region-wide processes that were taking place between the $3^{\text {rd }}$ and the $2^{\text {nd }}$ millennium BC.

\section{THE STATE OF RESEARCH: CHRONOLOGICAL AND CONCEPTUAL FRAMEWORKS}

The study of the later Early Bronze Age phase and of the transition from the Early to the Middle Bronze Age is intrinsically connected with the investigation of processes of formation, crisis/collapse, and regeneration of urban societies in the northern Levant during the centuries from c. 3000 to $c .1900 \mathrm{BC}$, that is from Early Bronze II to Middle Bronze I. Within this long timespan, the period between c. 2300 and c. $1900 \mathrm{BC}$ is associated with the examination of mechanisms that led to the transition from differentiated local trajectories in the Early Bronze Age to a homogenized socio-cultural complex in the Middle Bronze Age. The latter phenomenon is often referred to as the Amorite koine, happening within an Amorite oikumene (Schwartz 2013a; Burke 2014a; 2014b: 408-410; 2017: 264-266). However, it is increasingly accepted that the mechanisms that produced the homogenization were diverse, and not necessarily ascribable univocally to the emergence of the Amorites both at a political level and (presumably) in the archaeological record (Homsher, Cradic 2017; 2018; D’Andrea 2019a). Moreover, the centuries between c. 2300 to c. $1900 \mathrm{BC}$ are tied to the definition of timing and chronology of the shift from the Early to the Middle Bronze Ages in western inland Syria and of the synchronization of this event with the regional periodization schemes of the surrounding regions. Obviously, the definition of the chronological frame impacts on historical interpretations of connectivity and mechanisms that triggered political and sociocultural changes, possibly mirrored also by transformations of the material culture.

Traditional interpretations of Ebla's developmental trajectory between the mid- $3^{\text {rd }}$ millennium BC and the onset of the $2^{\text {nd }}$ millennium BC centered on a few key points. Firstly, between $c .2500$ to $c .2300$ BC Ebla par- 
ticipated in a phase of flourishing urbanization leading to archaic state formation in the Northern Levant and was, indeed, the regional capital of a kingdom that ideally extended from Karkemish on the Euphrates to around Hama in the central Orontes Valley. ${ }^{1}$ The Ebla kingdom was violently destroyed towards the end of the 24th century BC. Both Sargon and Naram-Sin of Akkad claimed that they destroyed Ebla, but according to some scholars Ebla was destroyed by Mari (Archi, Biga 2003; Sallaberger 2007: 422; Finkbeiner, Novák 2015: 12) or by a shakkannakku (literally general) of Mari on the orders of Sargon (Durand 2012). Besides, it has even been argued that a natural catastrophe might have been the catalyst for this destruction (Kennedy 2015: 311-312; 2016: 8, 19), though the latter proposal is based on a misunderstanding of the archaeological evidence (see infra). Yet still, Matthiae has discussed numerous historical and archaeological reasons why, in his view, Sargon is the most suitable candidate for the destruction of Ebla and suggested that in Naram-Sin's inscriptions the name Ebla is a pars pro toto and the king may have referred to the region of Ebla and not to the site itself (Matthiae 2010: $192=2021$ : 143). Until a few years ago, it was believed that the devastation of Palace G and the EB IVA city of Ebla would have caused decline at the site during the post-destruction phase in EB IVB, traditionally (and conventionally) dated to $c$. 2300-2000 BC. During the latter period, Ebla would have retained an urban status, despite a drastic reduction of monumentality compared to the previous EB IVA period, as a possible sign of shrinkage and abatement (Matthiae 1993: 619-621). Nonetheless, it was believed that during EB IVB Ebla might still have had some role in interregional connectivity, taking the Ur III-period texts from Drehem mentioning men from Ebla (Owen 1992: 117-122; Sallaberger 2007: 434-435) as evidence for contacts between the two cities in the $21^{\text {st }}$ century BC (Matthiae 2006b: 92 =2013b: 249; 2010: $204=2021$ : 152-153; 2020: 105; Dolce 2007: 184; Pinnock 2009: 71), corresponding to the late EB IVB in the traditional chronology. According to traditional narratives, at the onset of the $2^{\text {nd }}$ millennium BC and seemingly following a second destruction towards the end of EB IVB, Ebla would have been rebuilt with a new urban layout determined first and foremost by the outer ramparts possibly under the aegis of an Amorite leader, who might or might not have been responsible for the end of the EB IVB town (Matthiae 2009b: 187-188 = 2013a: 75-76; 2010: 204-298 = 2021: 153-154).

From the early 2000s until the most recent times, what happened at Ebla and, more generally, in Western Syria during the last quarter of the $3^{\text {rd }}$ millennium $\mathrm{BC}$ has been subject to an intense scholarly debate, centring on the one hand on investigating and understanding collapse, crisis, and transformation and on the other hand on tracking continuity and discontinuity between the Early and Middle Bronze Age traditions. In addition, the so-called "4.2 ka BP climatic event" and the connected migration hypotheses linking material culture transformations and social change to either intra- or inter-regional movements of people triggered by climatic change have played a part in the conceptual frameworks applied to the archaeological evidence of the EB IVB period from western inland Syria (e.g., Burke 2014a; 2014b; 2017; Weiss 2014; 2017; Kennedy 2016). Glenn Schwartz and Naomi F. Miller (Schwartz 2007; Schwartz, Miller 2007), 'ecofactual and artifactual' data at hand, discussed the difficulty of identifying widespread collapse during EB IVB, a notion that would prove correct ten years later with an increased body of data (Mazzoni 2013: 36-38; Cooper 2014: 288; Schwartz 2017: 114-116; D’Andrea 2019a: 16-24). However, the development of the regional sites during the latter period were still obscure until a few years ago, and the proposed interpretations somewhat biased by the lack of substantial stratified data, and synchronisms likewise.

As concerns periodization, ceramic chronology, and synchronisms, the question 'what to label the end of the Third millennium ceramic assemblages' (Porter 2007a: 73) arose from comparisons between the ceramic ensembles of the Ebla region and those of the Middle Euphrates Valley sites. In the wake of this debate, two proposals were put forward.

The first suggestion, advanced by Mazzoni and Felli (2007: 212-215, fig. 4) and Felli and Merluzzi (2008: 100-103) is that at some sites, such as Tell Afis, in the Ebla region, it was possible to isolate a transitional EBMB phase during which ceramic traits typical of both the Early and Middle Bronze Age traditions co-existed. This

\footnotetext{
${ }^{1}$ On the geographic extension of the Ebla kingdom, see, e.g., Archi 2015: fig. 1; Biga 2013; Bonechi 2016: 59, with different opinions concerning either the inclusion or exclusion of Hama from the territory of the Ebla kingdom; for the inclusion of Karkemish in the territory of the kingdom, see Fronzaroli 2003: 43.
} 
phase would be comparable with the transitional phase identified at some sites in the Middle Euphrates Valley and then called Phase 6 in the local, regional, sequence (Cooper 2006: 23-26, figs 1.8-1.9; Porter 2007a: 72-78; 2007b: 12-13, pl. VI), and now referred to as Early Middle Euphrates (EME) 6 after the ARCANE project (Sconzo 2015: 109,111 , and tab. 8, pls 28-30, 35). The latter phase is, in turn, similar ceramically to Phase Early Jazirah V (Orsi 2012: 91-95) now called Early Jazirah (EJZ) 5 according to the ARCANE's periodization scheme and terminology for the latter region (Rova 2011: 64-65, tab. 7 and Pls 21-25). The evidence from Tell Afis can be positively matched with that of Tell Mishrifeh/Qațna, in the central Orontes Valley. At the latter site Daniele Morandi Bonacossi (2008: 128-129, 131, 135-137, 149, and figs 15-19) has identified, within the EB IVB sequence excavated in Operation J, on the Acropolis of Qațna, a rather long timespan (Phases 20-18) during which the Early-to-Middle Bronze Age transition would have been accomplished, and only after which it would be possible to isolate the peak of the MB I (Phase 17) at this site (Morandi Bonacossi 2008: 146-147, 149, and fig. 24). In a technological study of the pottery, Marco Iamoni (2014: 20-21) confirmed this proposition from the petrographic point of view, showing that substantial changes in the modes of production of ceramics that would crystallize in the Middle Bronze Age began during EB IVB at Qațna. In fact, EB IVB, and especially the later stages, were accompanied by significant technological transformations that anticipate aspects typical of the Middle Bronze Age ceramic production, which would then clearly be accomplished at an 'industrial' scale. This is shown by the workshop area installed on the Acropolis in Phase 18 (late EB IVB or transitional EB/MB phase in Operation J) and remarkably enlarged in Phase 17 (early MB I phase in Operation J) (Morandi Bonacossi 2008: 136-137, 147-149, figs 20-23). Interestingly, 'industrial' workshop areas for pottery production appeared at several other sites across the Levant from the EB/MB transition and well into the MB I period (Morandi Bonacossi 2008, 428). Such pottery production areas can be found in western inland Syria at Tell Afis in Phase Afis IV/V (EB/MB phase) according to the excavators (Mazzoni, Felli 2007: 212, fig. 3; Felli, Merluzzi 2008: 98-101 and fig. 3), in Lebanon at Tell 'Arqa during Phase N, in the advanced stages of Level 14 (later part of MB I; Thalmann 2010: 99, fig. 20), and in Jordan at Tell el-Hayyat, in Phase 4 (MB I; Falconer, Fall 2006: 39-40, figs 3.12-3.15). This evidence is in accordance with Homsher and Cradic's (2017: 271, 275-276) interpretation of typological and techno-stylistic changes in the Levantine pottery of the Middle Bronze Age taking place at a region-wide scale and pointing to growing homogenization because of spreading technological innovation within high patterns of connectivity in the frame of the 'second-generation states' (definition by Schwartz 2013b: 498) of the Middle Bronze Age.

The second proposal that has gradually become popular from the early 2000 s, when it was advanced first by Ann Porter (2007a: 78-87 and chart 1), is that, based on ceramic parallels, the most suitable correlation between Phase 6/now EME 6 and Ebla's phases would not be with Mardikh IIB2 - corresponding to the EB IVB stratum - but with Mardikh IIIA - corresponding to the MB I stratum. A correlation has also been proposed between the Ur III period in southern Mesopotamia and EJZ 5 in the Jazirah, with MB I at Ebla and in western inland Syria rather than with EB IVB (Pruß 2007: 484-486; Schmidt 2012: 170-174, fig.10-13; 2014; Pfälzner 2017: 172-177), while others are more cautions (Schwartz 2017: 100) or hesitant (D’Andrea 2014-2015: 153-154, n. 8; 2016a: 201, fn. 5; 2016b: 218-220; 2018: 230-232; 2019b: 2274-276).

In this paper I would like to argue that there are two levels of analysis of this issue. One question is the relative, ceramic phasing of EB IVB and MB I, which may be re-addressed based on phased, primary, ceramic assemblages that were not available for scholars to see when the various suggestions of moving synchronisms between western and eastern regions of Syria were put forward. The other question is the absolute chronology of the EB IVB and MB I periods in western Syria, which is still in flux due to the paucity of reliable radiometric dates to define the boundaries of these phases within the timespan including the $21^{\text {st }}$ and the $19^{\text {th }}$ centuries $B C$. The latter consideration applies also to the definition of Phase EME 6 in the Euphrates Valley and EJZ 5 in the Syrian Jazirah. 


\section{EBLA DURING EARLY BRONZE IVB AND THE EB/MB TRANSITION}

\subsection{The Data from the 1964-2003 Excavations at Tell Mardikh}

The occurrence of the very distinctive Painted Simple Ware, which has been for decades the fossil directeur of the EB IVB period (Mazzoni 1985: 14-15; 2002: 79 and Pl. XLIV) made it possible to recognize an EB IVB presence at Ebla since the very beginning of the archaeological exploration at Tell Mardikh. Residual EB IVB sherds were found at several spots at the site (D’Andrea 2018: fig. 2), and an impressive amount of several hundred sherds of EB IVB pottery was collected in ash layers heaped in the ramparts (Mazzoni 1985: fig. 6: 2-4, 6-7, 11, 13-15, 17-20, 22-23; D'Andrea 2015: figs 1: 1-10, 14-17, 2; 2016a: 209-211 and figs 4: a and 5-8). The latter layers were interpreted by Matthiae (2009b: fn. 61 at pp. 62, 64, =2013b: 73, fn. 61) as the debris of the destruction of the EB IVB settlement cleared and used to accomplish the impressive earthworks at the beginning of the Middle Bronze Age. ${ }^{2}$ Beside secondary materials, architecture dating from this period was also uncovered: dwellings in Area T (Matthiae 1993: 615, 617, 619-621 and fig. 3) and the older phase (Phase I) of the Archaic Palace (Matthiae 1993: 638-640 and fig. 14; 1995: 654-655, fig. 2, 659-672, figs 7-17; 2006b: 92 and fig. $6=2013$ b: 248 and pl. 74; here Fig. 4), both in the Lower Town North and uncovered in the 1990s, and the remains of a temple on the Acropolis, uncovered in a sondage under the Temple of Ishtar of the Middle Bronze Age, excavated in 1966 (Floriani Squarciapino 1967: 69-72, tavv, XXVIII: 4, LX: 1-14) and extended in 1968 (here Fig. 5).

The major limit of the EB IVB evidence from Ebla available until 2003 was that it is only related to one-phase contexts dating from this period, or, in other words, that a long stratigraphic sequence from this period to use as a benchmark for the phasing and synchronization of the evidence from the different excavation areas at the site was lacking. However, with this chronological caveat, it was still possible to infer some information on the nature of the EB IVB settlement; therefore, preliminary assessments of the evidence were put forward by the archaeologists working at Ebla.

In her re-examinations of the evidence, Rita Dolce proposed that it might have taken a couple of generations for Ebla to recover from the destruction, and that a process of recovery should have started after the end of the Akkadian period (Dolce 2007: 174), following the abandonment of the site after the end of EB IVA and a shortterm gap (contra Matthiae 1995: 125; 2020: 101). This gap would have been followed by the restart of construction activities in several sectors of the Lower Town in particular, according to a new urban layout compared to EB IVA, which would be kept in the Middle Bronze Age. This event would have inaugurated a thriving phase of life of the new settlement (Dolce 2007: 183-184, 188) under the aegis of a new ruling dynasty (Dolce 1999: 293-295, 297; 2007: 175-176 and fig. 9; see also Dolce 2001: 21-25). Dolce also suggested that in the EB IVB urban pattern some earlier foci of political power and cult were preserved and actually persisted through the long developmental trajectory between EB IVA and MB II (Dolce 2009: 275-276), and in particular from the EB IVB centre to the 'Amorite' city' (Dolce 2009: 267), like some secular and public buildings on the Acropolis. The latter hypothesis was based on the persistence of cult buildings in Area D, and possibly in Areas N, and P (see Dolce 2001: 17; Pinnock 2004: 93, figs 2-3; D’Andrea 2014-2015: 135, fig. 3), and on the notion of ash layers with EB IVB pottery sherds under the courtyard of the later Middle Bronze Age Palace E, which have been later re-ascribed to EB IVA (see Matthiae 2020: 101 and footnote 2 here). A connection between the EB IVB and MB I traditions at Ebla was recognized also by Frances Pinnock (2009). Pinnock did not consider the two horizons as 'one and the same culture in evolution', though stressed the importance of continuity at Ebla, 'between the end of the $3^{\text {rd }}$ and the beginning of the $2^{\text {nd }}$ millennium BC' (Pinnock 2009: 79) - meaning, in the traditional chronology, between EB IVB and MB I - in the representation of kingship in art and urban principles, as well as in royal onomastics.

\footnotetext{
${ }^{2}$ It was earlier asserted that further ash layers containing EB IVB pottery were identified on the Acropolis, in a limited probe in the courtyard of the monumental building in Area E interpreted as the Royal Palace of the later Middle Bronze Age I-II phases (Fronzaroli 1967: 81-82; Matthiae 1995: 132). However, Matthiae (2011: 743-761, in particular 751; 2020: 101) has subsequently revised this statement in light of the 2008-2010 excavations on the Acropolis that showed that everywhere in the northern and western sectors the Middle Bronze Age and later architecture were set directly above the EB IVA destruction layer. In fact, the pottery from the sounding published by Fronzaroli in 1967 looks EB IVA in date rather than EB IVB.
} 
In a 2007 reconsideration of the evidence from Ebla at the EB-MB transition, Stefania Mazzoni and Candida Felli (2007: 208-209) pointed out that, in the state of research of that time, from the available archaeological evidence and epigraphic records (Ur III texts mentioning Ebla, the inscription on the torso of Ibbit Lim's statue, and Ib-Damu's seal from Kültepe/Kanesh) it was not possible to infer sufficient data to determine critical chronological (both relative and absolute) turning points in Ebla's developmental trajectory between the end of EB IVA and the beginning of MB I. These crucial yet chronologically indistinct aspects were:

1) Whether there had been a hiatus between EB IVA and IVB;

2) The duration and phasing of re-urbanization in EB IVB;

3) The existence and extent of disruption between EB IVB and MB I.

Mazzoni and Felli also stressed the importance of defining whether urban regeneration at Ebla (with the construction of the rampart and the new urban layout) would have taken place within the chronological framework of the Ur III-period or the post-Ur III period horizon based, respectively, on different proposed dates for the IbbitLim inscription to either the Ur III period (Frayne 1990: 807) or MB I (Gelb 1984: 213-229; Archi 2002: 26). The two options would place this event, respectively, 'within a context of Ur III primacy' or in a new sociocultural and socio-political framework characterized by the advent of Amorites (Mazzoni, Felli 2007: 208). The latter proposition is related to traditional interpretative paradigms seeing the political and economic emergence of Amorites as a Middle Bronze Age phenomenon. Finally, Mazzoni and Felli (2007: 209) suggested that, in their view, the most suitable reading of the then available archaeological data for the EB/MB transition at Ebla was 'a process of cultural continuity (...) ascertained by material culture in connection with a stratigraphic sequence showing apparently no break in the occupational history of the site'. They also maintained that 'the re-structuring of the early MB I Ebla can be interpreted not as a revival after a collapse but as the apex of a trend that had already started in the course of EB IVB and which included economic stability and, eventually, growth and political stability' (Mazzoni, Felli 2007: 209).

In the following paragraphs, I will discuss the importance of the evidence excavated from 2004 to 2008 and the subsequent data processing to answer the questions listed above, and use my own research on Ebla in the EB IVB period carried out during the past years to support the view of some degree of continuity in the occupation of the settlement between EB IVB and MB I, as well as to explore the hypothesis of a connection between the two periods in terms of sociocultural and socio-political dynamics taking place at the site and its region. Above all, I will discuss how to analyse these phenomena on a deep chronological scale may allow us to frame them historically and conceptually, shedding light on the factors that made Ebla's urban regeneration possible and the potential agents of this resurgence, and bringing resilience into the discourse as a decisive mechanism for possible EB IVB/ MB I continuity in some socio-political structures that might have ensured stability and growth notwithstanding a destruction in between.

\subsection{Results of Research at Ebla from 2004-Present}

In 2004, the decision to start excavations in Area HH in the Lower Town South-East yielded an unprecedented opportunity to investigate and understand in a better way the Early Bronze IVB sequence at Ebla. Paolo Matthiae (2006a: 470-475; 2007: 493-512; 2009a: 773-777; 2010: 191-208, 390, 395-398; 2020: 95-105; 2021: 143154, 299-300, 303-306) and the current author (D'Andrea 2014-2015; 2016a; 2018; 2020a) have described and analysed this sequence in detail, but it will be useful to summarize the main stages below (Tab. I).

The destruction that brought the EB IVA city to an end, and which is well documented in the Palace G rooms on the Acropolis, was detected only in a limited sector of the Temple of the Rock in Area HH because of later clearing operations. In fact, possibly soon after the destruction - as is suggested by lingering EB IVA traits in the pottery assemblages of the earliest EB IVB phase in this area (EB IVB1a) - the Temple of the Rock underwent a sort of termination ritual, including cleaning and clearing the debris, the deposition of a group of pottery vessels in the cavities of the cella, and the ritual sealing of the cella and antecella with several courses of mudbricks and a 
thick layer of crushed limestone devoid of any archaeological material. Soon after, still in the early EB IVB phase (EB IVB1b), retaining walls were built along the outer perimeter walls and on the front of the by then no-longerused temple, and dwellings were built and used along the northern and western perimeter walls of the temple.

In the following phase (EB IVB2), some new activities were started, with levelling and still somewhat enigmatic architecture that may be connected, as possible substruction(?), with the reorganization of the area as a sacred compound in the following phase (EB IVB3), with a temple proper - Temple HH4 - flanked by a smaller shrine Temple HH5 (Fig. 6). The ceramic phasing associated with the stratigraphic sequence in Area HH has allowed us to synchronize with this sequence the EB IVB evidence uncovered in the other areas of the site. It was thus possible to understand that not just the dwellings in Area T, but also the first construction phase of the Archaic Palace (Phase I), and the construction and use of Temple D3 on the Acropolis may correspond to this late EB IVB stage in Area HH. Moreover, following a reconsideration of the pottery from two tombs excavated in the basal level of the rampart in Area $\mathrm{Z}$ based on new parallels from Area $\mathrm{HH}$, I have proposed to redate them (originally ascribed to $\mathrm{MB} \mathrm{I}$ as the rest of the tombs dug into the rampart in this area) to the late EB IVB period. ${ }^{3}$ In my view, it is likely that, at Ebla, roughly at the same time when Temple D3 on the Acropolis (Figs 3,5) and the religious complex including Temple HH4 and Temple HH5 in the Lower Town south-east (Fig. 6) were built, the construction of the ramparts might have started (D’Andrea 2019a: 20, 23-24 and figs 16-17), like the beginning of the construction of the Archaic Palace (Fig. 4).

The construction projects of the Archaic Palace and of the rampart would have been interrupted by the destruction, ${ }^{4}$ which was identified in the western sector of Area HH (Matthiae 2006a: 471, 474 and fn. 48) and which Matthiae recently, tentatively, ascribed to an expedition led by Shu-Suen against Ebla and other cities in the western regions (Matthiae 2010: 206-207 = 2021: 153; 2020: 101-105, with bibliography). However, construction works might have been resumed soon after that event and accomplished during the Middle Bronze Age, when the Archaic Palace was modified, completed, and finally used (Phase II, followed by Phases III-IV, all still in MB I; Matthiae 2006b: 87-91, figs 3-5 = 2013b: 246). The evidence of several tombs spanning (ceramically) the whole length of the MB I and the beginning of MB II dug into the upper (compared to the two, possibly EB IV, tombs mentioned above) layers of the rampart in Area Z (Baffi Guardata 2000: 56) is suggestive that the completion of the rampart took quite some time (on this aspect, see also Nadali 2018: 295-297). This new (or newly understood) evidence for EB IVB/MB I continuity suggests that whoever was the responsible for the second destruction of Ebla this still disturbing event might not have been as dramatic or at least not widespread as the devastation of the Early Bronze IVA city had been (see Dolce 2009: 268-269).

In fact, there is one more, apparently minor but indeed very important, piece of evidence in between the destruction of the late EB IVB settlement and the early MB I city, that is the presence of a well-defined phase (EB IVB 4) of architecturally modest, but certainly sedentary, occupation following the destruction in Area $\mathrm{HH}$ (D’Andrea 2020a: 59 and fig. 7; here Fig. 7). In past publications (D’Andrea 2014-2015: 138-139, tab. II; 2016a:

\footnotetext{
${ }^{3}$ Mazzoni and Felli (2007: 207) and Mazzoni (2013: 51, fn. 86) had earlier suggested an EB IVB or EB/MB transitional date for the vessels int these two tombs (D. 6707 and D.6709), but their presence in the Middle Bronze Age rampart was considered as evidence for the construction of the rampart at the very beginning of the Middle Bronze Age. The chronological and historical implications of this datum for raising the date of the beginning of the construction of the rampart towards the end of EB IVB, before the destruction, have been discussed for the first time, together with the relative stratigraphic information, in D'Andrea 2019a, 20, 23-24 and figs 16-17.

${ }^{4}$ It is important to call attention to the fact that no EB IVB destruction layer has been identified in the rooms of the Archaic Palace, which might be either taken as a suggestion that the EB IVB destruction was not as ubiquitous as the EB IVA destruction, or that cleaning and clearing the debris happened when building activities were resumed in the early MB I stage, and the palace was accomplished and used. In some recent works (Kennedy 2015: 311-312; 2016: 8, 19) floor subsidence in the Archaic Palace has been taken as evidence for a natural catastrophe bringing the EB IVB settlement to an end, but this is due to an erroneous correlation of this piece of evidence with the phasing of the Archaic Palace. In fact, the floor showing clear signs of subsidence, which Matthiae (1995: 672) has connected with an earthquake, are those of the last MB I phase of use of the building, Phase IV (Matthiae 1995: 673, fig. $17 ; 2006 \mathrm{~b}=2013 \mathrm{~b}: 245)$, not those of the EB IVB period, Phase I.
} 
203; 2018: 233 and fig. 4; 2020a, 59, 62, tab. 1 and fig. 7; Matthiae 2009a: 64, fn. 16; 2009b: 64 = 2013b: 74; 2020: 96, fig. 5.2; see also Mazzoni 2013: 47), we have called this a 'squatters' reoccupation'. However, this definition should be probably changed to a description that emphasizes continuity of settlement with the previous inhabitants of the later EB IVB town (those who erected the temples, started to build the Archaic Palace, and possibly also initiated the construction of the rampart), as well as with the following phase of reconstruction, of which these individuals who remained at the site might have been the agents. Marked continuity between the pre- and post-destruction EB IVB phases at Ebla is strongly documented by pottery assemblages that may be ascribed to a terminal EB IVB horizon (Matthiae 2010: 205 = 2021: 150; 2020: 100 and fig. 5.8) with no sign of regression (see below). In my view, also considering the growing signs of continuity in the settlement between late EB IVB and early MB I, the presence of proper architecture, albeit unremarkable, may be interpreted as evidence for a phase of resilience after the destruction, albeit possibly short. Such a phase might have allowed the local community to get reorganized during $\mathrm{MB}$ I and to complete the construction works began at the end of EB IVB probably without letting too much time elapse after the destruction.

This new segment of Ebla's sequence is key to understanding the site developmental trajectory between the Early and Middle Bronze Ages and may be crucial to explaining continuity between the two periods in material culture and in the new urban layout. In fact, as for the first aspect, clearly continuity in the material culture included not just the pottery, but also the layout of temples (Figs 2-3). The two main Middle Bronze Age types - the bipartite temple in antis with longroom cella and the tripartite temple in antis (Fig. 8) - emerged from the architectural solutions elaborated during the late EB IVB phase that are well represented by the bipartite Temple HH 4 with longroom cella and by Temple D3, tripartite although still with a broadroom cella (Matthiae 2015: 80-85, 90, figs 4-5, 19-22; here see, respectively, Fig. 8: 3 and 8: 7). As for the second aspect, it seems ever more possible that a new urban layout including the outer rampart and a new seat of political power in the Lower Town (the Archaic Palace), and temples in Area D on the Acropolis and in Area HH was first conceived during the late EB IVB phase and maintained in the early Middle Bronze I phase (and even subsequently, although with further changes). In fact, all the main elements already present in the late EB IVB town, either accomplished - as Temple HH4 and HH5 and Temple D35 - or under construction - as the rampart and the Archaic Palace - mirror those that would typify the early MB I settlement. The possibility that Ebla's MB I urban layout was largely based on that of the EB IVB period was already suggested by Dolce (1999: 293, 298; 2007: 184; 2009: 267, see also Pinnock 2004: 93-95), Mazzoni and Felli (2007: 209, 219) argued that the reuse of the Archaic Palace between EB IVB and MB I might have been a sign of remarkable continuity of political structures between these two periods (see also Bonechi 1997: 36, fn. 25). In this author's view, this may not contrast with Matthiae's (2006b: $94=2013 \mathrm{a}$ : 250) interpretation of the earliest MB I phase of the Archaic Palace (Phase II) as a stage of decreased monumentality of the building compared to the ambitious project of the late EB IVB, and that, in this early MB I stage, the palace might have had a temporary "open" and somewhat peripheral reception unit. This hypothesis would fit in a scenario of recovery from a destruction, although in a slightly more advanced phase compared to the terminal EB IVB phase (EB IVB4) and when a Middle Bronze Age material culture proper had emerged at Ebla (Fig. 13), as at other sites in western Syria (see, e.g., Tell Afis Phase Afis V, Qatna Phase 17 in Operation J).

In MB I, the two sacred areas on the Acropolis and in the Lower Town south-east at Ebla were enhanced with the construction of two new temples above those of the EB IVB period (Figs 2-3). Temple D is patently a monumental structure (Fig. 3), and, although Temple HH 3 was very poorly preserved and razed (Fig. 9), it was possible to ascertain that it was built directly above the EB IVB Temple HH4. However, it was only later in the Middle Bronze Age sequence that the urban layout of the settlement changed with the establishment of a series of public buildings in the Lower Town in a large strip of land surrounding the slopes of the Acropolis, thus far uncovered on the northern, western, and southern sides, and with the construction of Palace E on the Acropolis (Fig. 1).

\footnotetext{
${ }^{5}$ It has been suggested that an EB IVB temple might have preceded the MB I cult buildings also in Area P and N (see a summary in D'Andrea 2014-2015, 135, fig. 3, citing earlier references). However, this has not been considered here because of the current impossibility to define the date of these earlier structures within EB IVB even in terms of relative chronology and phasing.
} 
Continuity between late EB IVB and early MB I could be framed within urban regeneration taking place throughout these periods under the aegis of a 'new' sociocultural component progressively risen to power during the reorganization process started in western Syria after the wane of the EB IVA Ebla kingdom and gradually accomplished during EB IVB through mechanisms that still largely elude our understanding. The most important implication of this hypothesis might be that sociocultural transformations that are traditionally considered typical of the Middle Bronze Age - the achievement of economic and political primacy by Amorites in north-western Syria - might have in fact begun during the later EB IVB phases (D’Andrea 2019a: 26). Weiss (2014: 376-377; 2017: 154-146) and Burke (2017) already suggested that substantial groups of Amorites were present in the northern Levant during the last century of the third millennium BC and Burke (2017: 270-271, 287-296) even proposed that they might have taken on political and economic power at major regional centres. However, here we argue that rather than "habitattracking" migrants (Weiss 2014: 374-375, 378; 2017: 145) or refugees (Burke 2017: 275-282, 287-296), such Amorites populations would have had stronger local roots, their presence in northwest inland Syria being already attested since at least EB IVA, as it can be appreciated, for instance, from the Ebla texts dating to the 24th century BC. Their rise to political and economic pre-eminence during EB IVB might be situated in a more general regional renegotiation of powers that might have followed the end of Ebla's EB IVA kingdom. Thus, in contrast to endogenous explanations for an EB IVB Amorite presence in the Ebla region, we propose a different, more endogenous interpretation and suggest that the new elites of the later EB IVB phase at Ebla might have emerged already from a sociocultural element that was previously a component of the local EB IVA society but was not in power at that time and that we may call, in the broadest sense, Amorite (on this issue, see Porter 2012: 309-312). This social component might have been able to achieve control of pivotal economic activities in the regional reorganization of the EB IVB period, following the fall of Ebla, and, this way, to rise also to political power (Nichols and Weber's [2006: 50] 'emerging "innovative" elites'). The proposed reconstruction may allow us to reconsider also striking aspects of continuity in intangible cultural aspects between EB IVA and MB I, such as royal onomastics, ideology, and collective memory, that had been noticed before though then framed within a different conceptual scaffolding pivoting on the notion that EB IVB was a phase of regression when EB IVA traditions were kept (Matthiae 1993: 619-621).

\subsection{The pottery and the intra- and interregional synchronisms}

With the developmental trajectory delineated above for Ebla between late EB IVB and MB I in mind, let us now turn to the ceramic evidence for these periods, and to how the new stratified data from the 2004-2007 excavations in Area $\mathrm{HH}$ and the 2008 excavations in Area D may give novel insights on (and possibly contribute to a clarification of) synchronisms between Ebla and other sites in western inland Syria, like Tell Afis in Phases Afis IV/V and V, and Qatna in Phases 20-17 in Operation J, as well as between Ebla and sites in the Syrian Jazirah, like Tell Mozan during Phase C7.

The study of primary stratified assemblages of the late EB IVB phase (EB IVB3) in Area $\mathrm{HH}$ at Ebla (D’Andrea 2014-2015: 146; 2018: 225-229; 2019b: 268-270 and figs 5-10; 2020a: 78-79; here Fig. 10) clearly show that this phase was characterized by the following elements:

1) Long-lived EB IVB vessel types such as Simple Painted Ware vessels (Fig. 10: 1-3) and bowls with profiled rims (Fig. 10: 4-5);

2) Late EB IVB types such as unpainted goblets (Fig. 10: 6), either plain, with comb-incised decoration, or with grooved rims, and bowls with triple grooved rim and/or bowls with vertical rims (Fig. 10: 7);

3) Late EB IVB types that can be considered harbingers of the Middle Bronze Age tradition (Fig. 10: 8-9), in particular bowls with round carination and beaded rim (Fig. 10: 9).

These trends recur in comparable assemblages from Area T (Fig. 10: 10-21) and Area D (Fig.10: 22-29) dating from the late EB IVB (EB IVB 3) phase.

Evidently there are no late EB IVB assemblages where ceramic elements typical of the EB IVB and MB I traditions co-exist - in contrast to what was proposed for Tell Afis in Phase IV/V and Qatna in Phases 20-18 (Opera- 
tion J). Forerunners of the Middle Bronze Age tradition can be observed at Ebla (Fig. 10: 8-9, 16-19, 22, 27-29), although they are not yet MB I vessels proper non only in terms of shapes (D'Andrea 2018: 228, 232-233; 2020a: 78-79; 2019b: 146, 151 and fig. 12: 12, 18-19) but probably also in terms of fabrics, though this needs to be further investigated by means of petrographic studies. These late EB IVB harbingers of the MB I tradition document the beginning of a development that, in the long run, would have eventually evolved into the MB I types if there had been no destruction, as it is visible at the two above-mentioned sites, but by no means represent a transitional EB/ $\mathrm{MB}$ ceramic phase at Ebla. ${ }^{6}$ It is a normal process of ceramic developments that innovations typical of a new tradition begin to emerge next to those of the older tradition until they replace them. At Ebla we cannot follow the whole process of gradual change and transformation observed at Tell Afis and Qatna, because of the destruction at the end of the late EB IVB phase. In fact, although the latter event was followed by continuity in the settlement and resilience, it certainly entailed a break in the development of ceramic industries, albeit short and localized. This may also be suggested by the fact that the pottery of the post-destruction phase (EB IVB4; Fig. 11) is represented by an EB IVB horizon, albeit a terminal one, which is closer to the preceding EB IVB3 ceramic phase at Ebla and to Phase Afis IV at Tell Afis than to the EB/MB transitional phases at Tell Afis (Phase IV/V) and Qaṭna (Phases 20-18 in Operation J) (Tab. II). Unfortunately, continuous construction and use of Area HH, especially in the temple area, with much clearing and levelling undergoing in-between the different phases made it impossible to recover any pottery from Temple's $\mathrm{HH} 3$ floors that would allow us to date ceramically the phase of use of this building. In fact, the remains of Temple $\mathrm{HH} 3$ were poor and razed, and covered with a thick layer of limestone gravel that served as a foundation for Temple HH2 (Fig. 13). The early MB I ceramic phase at Ebla is thus far documented by pottery assemblages from other sectors of the site, in particular from the Archaic Palace (Phase II). These assemblages illustrate a fully MB I ceramic horizon, although an archaic one, whose typological traits were described earlier by Lorenzo Nigro (2002: 101-104, and tab. 7, Pls XLVI: 1-6, 9-13, XLVII: 14-16, 18-26; 2009: 289-320) - his MB IA - and were recently discussed also by Luca Peyronel (2019: 747-750). In particular, the assemblages of Phase II of the Archaic Palace (here Fig. 13) originate from archaeological contexts that lay just above the EB IVB layers. Mazzoni and Felli (2007: 214) suggested that vessel shapes comparable to those of the earliest MB I phase at Ebla do not show up at Tell Afis before the dismissal of the workshop area ascribed to the $\mathrm{EB} / \mathrm{MB}$ transitional phase at the site, confirming our proposed synchronization of the latter phase after EB IVB3 and before MB I at Ebla, that is parallel to Ebla's EB IVB4, the post-destruction phase (Tab. II).

Now that we have defined what Ebla's late EB IVB, terminal EB IVB, and archaic, initial MB I ceramic assemblages may look like respectively and synchronized them with late EB IVB, EB/MB transitional, and early MB I phases at other sites in western inland Syria, let us turn to the question of proposed synchronisms of western inland Syria with the Middle Euphrates and the Syrian Jazirah. The present author already pointed out (D'Andrea 2018: 232) that the proposed comparisons between Ebla's MB I pottery and Mozan C7 Ur III-related ceramics ${ }^{7}$ were established based on pottery assemblages that do not represent the beginning of MB I at Ebla, but date from a later phase, when the Middle Bronze Age pottery tradition was well established at the site, as well as, more generally, in Syria as a whole. My intention was then as it is now to raise attention to the existence of a much longer ceramic sequence at Ebla than thought before, spanning all through the EB IVB period and well into MB I. This sequence comprises segments of the ceramic sequence that are in the process of being prepared for final publication and that, at least for what concerns $\mathrm{EB}$ IVB and the EB/MB transition have been partially published during the past five years (D’Andrea 2014-2015; 2016a; 2018; 2019b; 2020a).

If, on the one hand, it cannot be denied that there are similarities between the Mozan C7 pottery and the MB I pottery from Ebla, on the other hand there are parallels also between the late EB IVB assemblages of Ebla

\footnotetext{
${ }^{6}$ A different interpretation of these assemblages was offered by M. Alkhalid (2014-2015, 168-170, fig. 6; 2018, in particular pp. 264269).

${ }^{7}$ An Ur III-period date for the Mozan C7 pottery is also based on the style of seal impressions found in the house, as well as on Puššam's seal itself, which can be compared to southern Mesopotamian Ur III-period seals (Pfälzner 2017: 164) and is dated paleographically to a period between the late Sargonic and the Ur III period (Pfälzner 2017: 166).
} 
and Mozan C7. In previous studies (D’Andrea 2014-2015: 153-154, n. 8; 2016a: 201, fn. 5; 2018: 231-232), I have focused on carinated bowls, as these vessel types are taken as evidence of a possible ceramic synchronization between Ebla's phase Mardikh IIIA, Tell Mozan Phase C7, and Uruk's Ur III period, though not alone (Schmidt 2012, 170-174, fig.10-13, tab. 3, carinated bowls on fig. 10:-12, 45-, 12:1, 5; 2014; reprised by Pfälzner 2017, 172177, carinated bowls on fig. 7.1 and 7.8 at the top). Unpublished data at hand, I have shown that comparable vessels do appear in late and terminal EB IVB pottery assemblages from Ebla (here Fig. 14: 1). Likewise, if one wants to find more parallels for Ur III vessels in the Ebla region's ceramic repertoire looking at small jars, it should be considered that, albeit fragmentary, necked small jars with restricted slightly flaring neck and upright triple-grooved rims appear in later EB IVB assemblages as well (Fig. 14: 2-4).

There is another, unpublished, piece of evidence that may bear on correlations with Mozan Phase C7. In fact, in the late EB IVB3 assemblages there are a few painted fragments (Figs 14: 5-6 and 15: 1-4) that, though not being identical to those in the assemblages of Mozan C7, may have connections to pottery vessels considered by Pfälzner as early specimens of Khabur Ware - which he has assigned to the site's pottery period 'Habur Ia' and dated to his Early Jazirah V phase (= EJZ 5), 2100-2000 BC (Pfälzner 2017, 168-169 and tabs 7.1, 7.5), preceding chronologically Kolinski’s 'Early Khabur Ware' (Koliński 2014). One specimen is a fragment of a small carinated bowl with upright slightly thickened outside rim and reddish-brown painted horizontal bands (Figs 14: 5; 16: 1; compare to Pfälzner 2017, 170-171, figs 7.5: K 1141, 7.6:c; here Fig. 14: 9). In the absence of petrographic analysis of the small carinated bowl from Ebla, it is impossible to push connections between the two sites any further. The second group of pottery fragments is represented by necked jars decorated with a recurrent, brown-painted schema composed of groups of horizontal bands framing groups of smaller oblique lines forming triangular patterns (Figs 14: 6; 15: 2-4), which resemble those found at Tell Mozan (Pfälzner 2017: 169-170, figs 7.5: K 1144, 7.6: b; here see Fig. 14: 10). On such vessels from both sites, the painted motifs are 'cursory' and the paint is 'transparent', as noted by Pfälzner. Only petrographic analysis might determine the origin (local or non-local) of the Ebla sherds, but it is possible that these vessels represent a local ware class blending local elements (for example the pastes) ${ }^{8}$ and decorative traits of the eastern tradition of the earlier Khabur Ware.

The phased assemblages shown here (Figs 11-12, 14: 1-6, 15) as illustrative of late EB IVB, terminal EB IVB and early MB I at Ebla indicate clearly that other vessel types comparable to Phase C7 at Tell Mozan do not appear at Ebla until the beginning of Phase Mardikh IIIA1.

We may harmonize the fact that vessel shapes that will typify the MB I tradition at Ebla seem to appear earlier at sites in the Middle Euphrates Valley and the Syrian Jazirah with the observation that other traits of Ebla's late and terminal EB IVB corpus can be positively compared to pottery vessels of the other two regions. This consideration might allow us to keep the traditional synchronisms of Phase 6/EME 6 in the Middle Euphrates and phase Early Jazirah V/EJZ 5 with late EB IVB at Ebla, at least in part; this would not contrast with the possibility of an overlap of those two archaeological facies in the Euphrates Valley and northeast Syria also with early MB I in north-western inland Syria (D'Andrea 2016b: 220). It is overall possible that elements typical of a new archaeological facies or tradition may have begun earlier in the eastern regions of Syria, starting from the $21^{\text {st }}$ century BC, and more gradually in western inland Syria, with a different pace and rate at various sites during the $21^{\text {st }}$ century BC (Schwartz 2017: 100, 114; D’Andrea 2018: 232-233), with a new tradition beginning earlier in one region than in the other. In a way, this is also what we may observe in the difference between Ebla's post-destruction EB IVB4 ceramic phase and the transitional EB/MB horizons identified at Tell Afis (Phase Afis IV/V) and Qațna (Phases 20-18 in Operation J).

\footnotetext{
${ }^{8}$ With respect to this a large jar from Phase 18 at Qațna (late EB IVB or transitional EB/MB phase) shows comparable decorative schemas with parallel bands and triangles, but also the typical triple spirals of the EB IVB Painted Simple Ware of north-western inland Syria (Morandi Bonacossi 2008: 137 and fig. 19). Interestingly, Morandi Bonacossi reports that this jar was made with 'the socalled "transitional" fabrics decorated with a reddish-brown wash', though he suggests that the new motifs may recall the tradition of the Levantine Painted Ware of the MB I (Morandi Bonacossi 2008: 137). See D’Andrea 2015 for some discussion of this issue, based on particular EB IVB sherds of Painted Simple Ware from Ebla, with stylized animal figures and geometric designs.
} 


\subsection{Radiometric evidence and absolute dates}

Having set a preliminary framework for regional and interregional synchronisms based on relative ceramic chronology through stratified, phased, pottery assemblages, we should now look at the radiometric dataset for the three regions of Syria we have considered thus far - western inland Syria, the Middle Euphrates Valley, and the Syrian Jazirah. However, the radiometric evidence is both limited and problematic. Two main issues are radiometrically dating EB IVB, early MBI, and the EB/MB transition in western inland Syria and verifying radiometrically the suggested contemporaneity of the Ur III period in Mesopotamia and MB I in western inland Syria. A general scarcity of radiometric determinations for EB IVB and early MB I in western inland Syria, for EME 6 in the Middle Euphrates, and for EJZ 5 in the Syrian Jazirah as well as radiocarbon dates with very broad intervals further hamper synchronisms between these regions during the $21^{\text {st }}$ and $20^{\text {th }}$ centuries $\mathrm{BC}$. Moreover, the use of multiple different sets of absolute dates in different chronological systems makes it difficult to firmly establishing synchronisms.

Starting from Ebla, it is currently impossible to define the absolute chronology of the EB IVB period radiometrically, as there are no radiocarbon determinations associated with samples originating from EB IVB contexts. Radiocarbon dates of the destruction in Palace G yielded calibrated average intervals at 2348-2298 cal BC in the first standard deviation and at 2367-2293 cal BC in the second standard deviation (2-sigma) (Calcagnile, Quarta, D'Elia 2013: 454 and fig. 27.5). These dates provide a good terminus post quem for the beginning of EB IVB at the site in accordance with the traditional conventional absolute chronology for this period (Schwartz 2017: 88, tab. 1). Thanks to the stratigraphic sequence in Area $\mathrm{HH}$ we know that not too much time should have elapsed before the reoccupation of this area after the destruction. As for the EB IVB lower chronological boundary, it is currently impossible to date it radiometrically. The only radiocarbon determinations available are associated with MB I contexts and, even those, are not nestled in a long stratigraphic sequence.

Two radiocarbon dates belong to the midden in Area EE, which contains a remarkable number of archaic MB I pottery sherds and some EB IVA-B ceramics and is ascribed to an initial MB I phase (Peyronel 2019: 744-747, figs 5-8). Two charcoal samples from the midden yielded the following dates with rather broad intervals: $2140-$ $1910 \mathrm{cal} \mathrm{BC}$ (LTL-386A) and 1980-1740 cal BC (LTL-395A) (Fiorentino et al. 2008: tab. 2). Both these determinations might support the traditional chronology for the start of $\mathrm{MB}$ I at the beginning of the $20^{\text {th }}$ century $\mathrm{BC}$, although the first one might also be used to support an earlier start of the MB I at Ebla parallel to the Ur III period, but the secondary nature of the archaeological deposit does not allow us to take into consideration these dates to establish the chronological boundaries of MB I at Ebla. Two more reliable radiocarbon determinations were recently obtained from human skeletal remains originating from two of the tombs dug into the rampart in Area Z (Skourtanioti et al. 2020: e18): 2135-1964 cal BC (MAMS-41635; human tooth from burial D.7363) and 2026-1896 cal BC (MAMS-41116; human bone from burial D.6384), both dated ceramically to MB I, the former with rather standard MB I pottery, the latter with pottery of a late/final MB I phase (see Baffi Guardata 2000: fig. 8.1). It must be admitted that both dates are surprisingly high for the period to which the tombs can be ascribed ceramically and may provide some indication of where to place chronological boundaries for earlier and later MB I. However, again, the determinations have rather broad date estimates to embrace implicitly the proposal of a higher date for the beginning of the Middle Bronze Age at Ebla. In other words, what is needed to solve this issue is a series of modelled radiocarbon dates from a continuous EB IVB-MB I sequence that would allow for refined absolute phasing, associated with primary stratified pottery assemblages for each phase and sub-phase.

In addition, there is another piece of information that cannot be ignored in the definition of interregional synchronisms, though belonging to a different class of evidence: the discovery of seal impressions belonging to 'IbDamu king of Ebla' (meki-im ib-la) at Kültepe/Kanesh in the kārum II levels. This piece of evidence may allow a synchronism between the two sites to be established in the chronological frame of the Old Assyrian commercial outpost from 1930-1836 BC (Morandi 2014: 415). In fact, even if the seal was reused, it cannot be too much older than the time of its first use, as it can be placed in a clear Middle Bronze Age material culture horizon from the point of view of glyptic art (Pinnock 2000; 2004: 97). 
A later MB I tomb excavated at Qațna in Operation H (Morandi Bonacossi 2011: 15, figs 6-7) yielded absolute date ranges that are as broad as those from Ebla, but with lower date estimates: $3479 \pm 45 \mathrm{BP}$, corresponding to 1920-1680 cal BC, in the 1-sigma range and to 1880-1740 cal BC, in the 2-sigma range (LTL2048A, from Tomb G 17). Moreover, a tomb in the same location that has been dated by the excavators to the EB IV/MB I transition yielded absolute date ranges consistent with those of the traditional chronology: 2200-1950 cal BC, 1-sigma, 2140-1980 cal BC, 2-sigma (LTL2049A, from Tomb G 26). The latter determinations in the two standard deviations originate from a skeleton that was associated with a bronze belt disk, which Morandi Bonacossi (2011: 24-25 and fig. 26) has compared to one found at Tell Mozan in a later third millennium BC context as well as to MB I bronze belts from burial contexts across the Levant. The stratified sequence on the acropolis of Qața provided a series of radiocarbon determinations that may allow the phasing of the timespan from late EB IV to early MB I periods to be better defined in western Syria (Morandi Bonacossi 2008: fig. 10). EB IVB Phases 25, 23, and 22 yielded, respectively, the following dates: 2400-2600 cal BC, 1-sigma, 2140-1760 cal BC, 2-sigma (GX28924); 2300-1750 cal BC, 1-sigma; 2150-1940 cal BC, 2-sigma (GX28921); and 2410-2130 cal BC, 1-sigma, 2310-2190 cal BC, 2-sigma (GX28920). Phases 20-18, which are those where the EB-MB transitional characteristics are expressed ceramically, provided the following dates, respectively: 2040-1620 cal BC, 1-sigma, 1940-1730 cal BC, 2-sigma (GX28919); 2200-1600 cal BC, 1-sigma, 1980-1740 cal BC, 2-sigma (GX28918); and 2060-1880 cal BC, 1-sigma, 2040-1920 cal BC, 2-sigma (GX28922). Finally, Phase 17, which is MB I proper, yielded the following date estimates: $3540 \pm 70 \mathrm{BP} / 2040-1680 \mathrm{cal} \mathrm{BC}$, 1-sigma, 1950-1740 cal BC, 2-sigma (GX28917). All in all, Morandi Bonacossi (2014: 414) estimated that calibrated dates from the site may place the transition from EB IVB to MB I at Qatna in the interval between 2040 and $1930 \mathrm{cal} \mathrm{BC}$, that is in keeping with the traditional chronology for the EB IVB and the MB I periods in western inland Syria with $2000 \mathrm{BC}$ as the ideal divide in between (Schwartz 2017: 88, tab. 5.1; see discussion in Matthiae 2020: 103). Similarly, samples from EB IVB Layers d and $\mathrm{c}$ in Square 15Gc at Tell Mastuma yielded, respectively, calibrated ranges at 2200-2130 cal BC, 1-sigma, and 2210-2120 cal BC, 2-sigma (UCIAMS-21675), and 2130-2080 cal BC, 1-sigma, and 2140-2010 cal BC, 2-sigma (UCIAMS-21676) (Nishiyama 2009: figs. 10.13-10.14), which are again consistent with the traditional chronology of the EB IVB period in the last quarter of the $3^{\text {rd }}$ millennium BC.

A further factor affecting our ability to positively match regional sequences by using absolute dates is that Phase 6/EME 6 in the Middle Euphrates and phase EJZ V/EZJ 5 of north-eastern Syria are ill-defined from the point of view of absolute chronology, due to the lack of radiocarbon determinations for EME 6 and the paucity of radiocarbon dates for EJZ 5. This implies that for both phases the upper boundary has been set at c. 2100 $\mathrm{BC}$ based on modelled dates for the preceding EME 5 and EJZ 4c phases, but the lower boundary has not been set (Decker, Drechsler, Sconzo 2015: and tabs 2-3 and fig. 14; Ristvet 2011: 322). Therefore, the absolute chronology of these regional phases is established on a conventional basis and based on the presence of EB IV and MB I-related pottery types and styles in the assemblages ascribed to these horizons. Further confusion may arise from the use of different chronological systems in various regional studies discussing the Ur III period in Mesopotamia, not just referring to the High, Middle, Low or Ultra Low Chronology, but even to different sets of absolute dates within the Middle Chronology schemes. Thus, for instance, Finkbeiner and Novák (2015: tab. 2), adopt the dates from 2035-1919 BC for the Ur III period, following Mebert's proposal of a Middle Chronology (MC) circa 70 years lower than traditional MC ( $\mathrm{rMC}_{70}$; Mebert 2010). They maintain that the $\mathrm{rMC}_{70}$ seems supported by the Middle Bronze Age characteristics of the Ur III pottery (Finkbeiner, Novák 2015, 12), citing Pruß’s study we have recalled before (Pruß 2007). Differently, Sallaberger (2011: 332-333, tab. 3) introduces a MC reduced by 40 years $\left(\mathrm{rMC}_{50}\right.$ ), placing the Ur III period from 2060-1953. ${ }^{9}$ Finally, Sallaberger and Shrakamp (2015: tab. 39) use a Middle Chronology reduced by 8 years placing the Ur III period from 2102-1995 BC. Recently, Manning et al. (2017) suggested that revised radiocarbon dates from Kültepe and Acemhöyük seem to indicate that the lower MC might be the most correct, and the one better harmonizing different regional chronologies, including synchronisms with Egypt. However, evidently the definition of absolute chronology associated with phasing in the regional peri-

\footnotetext{
${ }^{9}$ Not 2042-1953 BC as wrongly reported by D’Andrea 2016b: 218; 2019b: 275.
} 
odization schemes for north-western inland Syria, the Middle Euphrates River Valley, and the Syrian Jazirah still needs a substantial refining. Considering that absolute chronologies are in flux, also the evidence of similarities among ceramic assemblages of distant regions should be used very cautiously for chronological cross-correlation and should not be used to establish synchronisms expressed as absolute dates or historical periods until contemporaneity can be proved firmly.

The radiocarbon determinations obtained from samples taken from Phase C7 in the House of Puššm at Tell Mozan place this phase between 2200 and 2000 BC (Pfälzner 2017: 166-167 and fig. 7.4). This is, again, a broad range estimate, which partly overlaps with one of the $\mathrm{MB}$ I radiometric determinations from Ebla, as well as, nevertheless, with several EB IVB radiocarbon dates from Qațna reported above from their original publication sources. On the one hand, it is possible that the transition from the Early to the Middle Bronze Age in Syria took place earlier than thought before and that, therefore, it might have partly overlapped with the Ur III period in the Syrian Jazirah and southern Mesopotamia, as it may be suggested by the radiocarbon dates. On the other hand, I believe that there might be evidence for a possible correlation of Phase C7 at Tell Mozan with the late EB IVB horizon at Ebla. Not only this would not be contradicted by the radiometric evidence for this phase at Mozan that cannot be really used as a conclusive proof of different interregional synchronisms between eastern and western Syria because of the broad range estimates at 2200-2000 BC. It would also be supported by unpublished evidence of parallels between the Phase C7 ceramic assemblages of Tell Mozan and the EB IVB3 pottery ensembles of Ebla presented in this article.

\section{DISCUSSION AND CONCLUSIONS. THE EB/MB TRANSITION AT EBLA WITHIN THE LOCAL AND REGIONAL CONTEXTS}

The above discussion of the radiometric evidence at hand has showed that we are still unable to synchronize regional periodization schemes from western Syria, the Syrian Jazirah, and southern Mesopotamia based on absolute chronology. Another issue is how to correlate the few available absolute dates to historical periodization schemes (e.g., the Ur III period and the different chronological proposals; see discussion in Sallaberger 2007; 2011; Sallaberger, Schrakamp 2015) This is complicated by different chronological systems, not just among the High, Middle, Low, and Ultra-Low Chronologies, but even different Middle Chronologies, some differing quite substantially from each other. We have seen that there are two opposite trends: 1) one is to move the Ur III period to the MB I in the $20^{\text {th }}$ century BC based on reduced MC systems, on which the synchronisms between EME 6 and western Syrian MB I rests; 2) the other one is to move western Syria's MB I to the $21^{\text {st }}$ century based on the observation of possible ceramic similarities between sites in the Khabur region and Ebla. We have underlined that there are several issues hampering this kind of synchronisms, in particular due to the blurring absolute chronologies of EME 6, EJZ 5 and even the Syrian MB I, due to the paucity of C14 dates for the Middle Euphrates and the Syrian Jazirah, and the paucity of dates from western Syrian MB I. Among the radiometric determinations from western Syria, only those of Qatna are framed within a continuous EB IV-MB I sequence and seem to support the traditional chronology. The radiometric determinations from the MB I tombs of Ebla are slightly higher than it should be expected although still possibly also fitting the traditional chronology due to their broad dates estimate. Without trying to push this evidence too much in favour of either chronological proposal these dates just face us with how far we are from building a sound absolute chronology for the centuries leading to the transition from the Early to the Middle Bronze Age in Syria as a whole.

On the other hand, the unpublished pottery evidence we have presented in this article indicates that more work is needed also on relative, ceramic chronology and interregional synchronisms based on pottery types and styles. With respect to this, we have recalled that 'sloping horizons', as they have been originally defined by Lorenzo Nigro (2007: 367, 382), may exist in different regions, with Middle Bronze Age features appearing earlier at some sites and areas, and Early Bronze Age features lingering longer at others. Above all, we have demonstrated on

a sound stratigraphic basis that there is a precise segment of Ebla's EB IVB sequence - late EB IVB or EB IVB3 
- that can be securely placed not only before a terminal EB IVB phase and the earliest MB I phase at the site, but also clearly before the EB-MB transitional phases observed at Tell Afis. It is precisely this EB IVB3 phase at Ebla that shows pottery types and styles that may be compared to those of Phase C7 at Tell Mozan, including early carinated bowls and what might be a local subset of or at least a local ware class connected with Pfälzner's 'Huabur Ia'. Noteworthy, the latter ware class clearly emerged as an important component of the ceramic assemblages of the end of the $3^{\text {rd }}$ millennium BC at sites in the Khabur basin, including Tell Mozan in Phase C7 (Pfälzner 2017: $188,191,198)$. This important new piece of evidence is suggestive that synchronisms between western Syria and the Syrian Jazirah that have been hold true for some time might be reconsidered and that more work is needed to achieve a reliable synchronization between these distant regions with discrete sets of material culture, despite visible connections among them. To better understand the synchronization of these two regions of Syria between the late $3^{\text {rd }}$ and the early $2^{\text {nd }}$ millennium $\mathrm{BC}$ might be a potent tool for refining our interpretative frameworks for sociocultural transformations that resulted in the transition from the Early to Middle Bronze Age at a region-wide scale These transformations might have resulted from regional dynamics and processed that entailed high patterns of connectivity among sub-regions of Syria that were part of diverse 'cultural zones'.

Turning now to the sociocultural aspects of a possible major degree of continuity between EB IVB and MB I at Ebla than expected before, we must reconsider the site's developmental trajectory from the end of EB IVA to the beginning of MB I as we can now appreciate it in light of new data and through comparisons with the progressions of other regional sites during this quite long timespan.

We have mentioned earlier that EB IVB at Ebla was considered as a phase of decline and abatement despite the site's retention of an urban status (see, e.g., Matthiae 1993: 619-621; Dolce 2007: 184; 2009: 267), not just exemplified by the loss of the role as regional capital that the site had in EB IVA, but by a sensible decrease of monumentality compared to EB IVA. The possibility to frame the EB IVB phase when public architecture reappeared at Ebla within the stratigraphic sequence in Area $\mathrm{HH}$ for the latter period and the ensuing intra-site synchronization have allowed us to appreciate this stage as part of a progression in the later part of this sequence. This evolution led from crisis during EB IVB1 to reorganization during EB IVB2 and new growth during EB IVB3, followed by a destruction, a possibly short phase of resilience in EB IVB4, and the final accomplishment of urban regeneration at the site in $\mathrm{MB}$ I. The archaeological evidence seems to suggest that the agents of reorganization and new growth might have emerged from a renegotiation of political and economic power between different local components. These components might have been a more 'urban' one that had been in power during EB IVA, and a more 'tribal' one, though urbanized or at least connected tightly with the urban component, that was in power from the end of EB IVB onward (with important changes all through the period; see infra). ${ }^{10}$

As noticed in previous works (D’Andrea 2019a: 17-19; 2020b: 212; 2020d: 156, 161), the trajectory of Ebla goes all the way around compared to sites in other areas within the broader region, especially in central Syria. In fact, Qatna developed uninterruptedly all through EB IV, and sites at the western edge of the Syrian steppe thrived all through the period as well, seeing in the EB IVB a phase of expansion. There have been several explanations for this, which range from movements of people from other sites or areas - including refugees from Ebla after the destruction (Mazzoni 2013: 36) or from the Jazirah after the fall of the Akkadian Empire and the 4.2 ka climatic event (Weiss 2012; 2014: 370-379; 2017: 136-147; Burke 2017: 287-296). However, it seems more likely that an endogenous path was working, connected with new economic and political possibilities for the central Syrian sites after the wane of the Ebla kingdom (Kennedy 2015: 316-317; 2016: 4; D’Andrea 2019a: 17-19; 2020b: 212; 2020d: $156,161)$. This region of Syria east and southeast of Qața is traditionally identified with the territory of a political entity mentioned in the EB IVA Ebla texts, a tribal confederation called Ibal (with several possible chiefs) and showing an Amorite linguistic connection (Catagnoti 1997: 123), which was originally in conflict with Ebla until it was subdued (Biga 2014). The identification between the steppe area to the south and east of Qatna with Ibal has

\footnotetext{
${ }^{10}$ Matthiae (2009b: 188 , fn. $70=2013 \mathrm{a}: 75$, fn. 70 ) had adumbrated the possibility that a change in political power balances between urban and non-urban components might have been a factor behind socio-cultural changes in the transition from the Early to Middle Bronze Age, though framing this process within antagonistic relationships between the two parts.
} 
recently been questioned and it has been argued that there is some need of rethinking Ibal in terms of both spatial extension and socio-political organization (Catagnoti 2020: 234). However, this proposal does not per se contrast with the observation that the phase of intensification and growth of sites in this very region of Central Syria during EB IVB might have corresponded to recovered political and economic autonomy of this region after the wane of the mighty kingdom of Ebla (D'Andrea 2019a: 17-19; 2020b: 212). I have recently suggested that a reprise of contacts between Ebla and the sites in the central Syrian steppe in a mature EB IVB phase can be inferred based on ceramic evidence (D'Andrea 2020d: 153 and fig. 1). This renewed connectivity may account also for similarities observable between the religious complexes of Ebla and Al-Rawda (D'Andrea 2020c: 10-11; 2020d: 159), which were noticed before (Matthiae 2007: 504-505; Castel 2010: 142). If my interpretation of sociocultural transformations at Ebla during the advanced EB IVB phase is correct, then contacts with sites in Central Syria would have taken place no longer within the framework of EB IVA political relations, which might have been antagonistic to some extent at that time. EB IVB contacts might have happened within a new 'sociocultural order' when the new leadership of Ebla might have been closer, in terms of socio-cultural background, to the political leaders of the circular cities established in Central Syria (D’Andrea 2020c: 10; 2020d: 159; 2021: 4) at sites located at the western edge of the Badiya al-Sham (see, more recently, Castel 2020; Mouamar 2020). ${ }^{11}$

While we do not yet fully understand what happened at the transition from EB IV to MB I in this region of Central Syria, it seems clear that previous hypotheses of a crisis of settlements in this area connected with climate change may not be the only explanation. On the one hand, shifts toward dryer climatic conditions must be considered (especially at the microlocal level) among factors that might have triggered changes in patterns of settlement. On the other hand, a possible alternative model might be that of a change in landscape use, connected to a political reconfiguration. It is worth noting that this area was not abandoned in the Middle Bronze Age, as it was suggested before (Peyronel 2014: 124-125; Schwartz 2017: 116, 119-120); rather it seems possible that a concentration of population in a smaller number of larger sites occurred. While Tell Shayrat and Al-Rawda where no longer occupied in the MB I period, Qațna and Tell as-Sur (that both had circular plans in the Early Bronze Age) were still inhabited, and both underwent a radical modification of the urban layout with the construction of the rampart which may be interpreted as evidence for the concentration of a larger population than before in these settlements (Mazzoni 2013: 50-52). In fact, it is precisely in this phase that Qaṭna grew from 25 to 110 ha (Morandi Bonacossi 2016: 151). In addition, recent remote survey work suggested that, during the Middle Bronze Age, the whole marginal area of the Syrian steppe was dotted with a well-planned defensive system made of intervisible towers, fortresses and forts, whose spatial distribution seems to have been related to the major sites of this period Aleppo, Ebla, Tell Tuqan, Tell Nasriyah, Qațna, and Tell as-Sur (Rousset et al. 2017: 115, 135-144, and fig. 24). All in all, the archaeological evidence might correspond to the militarization of a political frontier in this phase, which was only demarcated by the still enigmatic feature discovered by the French team of the Marges Arides Project and dubbed the Trés Long Mur (TLM, meaning Very Long Wall) during the EB IV period. The inclusion, in the new system, of sites such as Ebla, Tell Tuqan, and Aleppo that were not bounded by the TLM, might be a consequence of a new socio-political configuration, emerged already at the end of EB IVB in the wake of renegotiation of political balances leading the 'Amorites' to get to power, and eventually crystallized during the Middle Bronze Age.

Seen from this new perspective, evidence of continuity and discontinuity in 'intangible' aspects at Ebla during MB I as compared to EB IV, in particular EB IVA, may acquire a new meaning. It was already noticed (Matthiae 2009b: 188; Mazzoni, Felli 2007: 206-209; Dolce 2009: 268; Pinnock 2004; 2009; D’Andrea 2019a: 20-26, figs 5-6, 8-10, 12-14; 2019b: 265, 267-272) that at Ebla there are striking aspects of ideological continuity with EB IVA at the beginning of the Middle Bronze Age. One is the deliberate retention of the sacredness of some places (Pinnock 2004 93-94, figs 2-3; 2009: 74). This phenomenon is visible in Area HH in the Lower Town south-east, and in Area D on the Acropolis, where, during EB IVB, temples are built in the same place where EB IVA sanctuaries

\footnotetext{
${ }^{11}$ If this hypothesis is correct, it may provide a sociocultural backdrop also for Matthiae's (2020: 101-105) proposal of a military campaign in the Ebla region during Shu-Suen's reign, framing this event within the Ur III king's intervention against the Amorites in the western regions.
} 
stood before. One aspect that has not been underlined thus far and that is fully appreciable in time-depth thanks to the synchronization of Ebla's EB IVB evidence made possible by the multi-phased sequence excavated in Area $\mathrm{HH}$, is that, in both areas, this return to holy places took place after a gap, only in the late EB IVB phase. This is clearly visible in Area $\mathrm{HH}$, where from the termination rituals in the Temple of the Rock to the construction of Temples HH4 and HH5 in EB IVB there is a phase in-between with a shift in function to domestic occupation in this sector of the site. This piece of evidence underlines a deliberate choice during the mature EB IVB phase to restore the sacredness of that place, which was kept also in the following Middle Bronze Age. This choice of ideal continuity in cult places relates to the advent to power of 'Amorite' leaders at several other places in the Middle Bronze I, including Tell Umm el-Marra, close to the Lake Jabbul, where a cult platform was built above the EB III-IVB elite burial complex (Weber, Nichols 2006: 46-47, 49-51). At Tell Brak/Nagar too, a similar process of preserving earlier cultic traditions in the new $2^{\text {nd }}$ millennium $\mathrm{BC}$ sociocultural milieu is suggested by the retention of the worship of the Belet-Nagar (Oates, Oates, McDonald 1997: 142).

Another aspect of striking deliberate continuity is royal onomastics, with the $2^{\text {nd }}$ millennium $B C$ political leaders of Ebla bearing non-Amorite names - Igrish-Heba, Ibbit-Lim, and Ib-Damu - modelled on those of the EB IVA kings - Igrish-Halab, Irkab-Damu, Ishar-Damu (Bonechi 1997). On the other hand, the most remarkable innovation at the time was the introduction of the worship of Ishtar at Ebla by King Ibbit-Lim, or, rather, the syncretism between Ishkhara (the main EB IVA goddess at Ebla) and Ishtar actualized by the king as suggested by Matthiae (2010: 210-211 = 2021: 156-158). This is stated by Ibbit-Lim himself in the inscription on his (fragmentary) statue from Ebla ascribed to the turn between the $3^{\text {rd }}$ and $2^{\text {nd }}$ millennium $B C$ on palaeographic ground (Gelb 1984) and dedicated 'in the eighth year after Ishtar had manifested herself in Ebla'. It is believed that the syncretism may be reflected by the creation of the term Ishtar Eblaitu, Ishtar of Ebla (Matthiae 2003; 2009b: 189). It has been observed that, although Ishtar was frequently mentioned in the EB IVA texts, it would have not been possible, in the cultural milieu of that time, that a king would put his dynasty under the protection of Ishtar as Ibbit-Lim did; therefore, this event must reflect a change in the cultural backdrop at the time of this king (Archi and Matthiae in Matthiae, Pinnock, Scandone Matthiae [eds] 1995: 408, n. 251). This event may look like a discontinuity with the local EB IVA tradition, but the observation that there may have been a syncretism and not a replacement somewhat mitigates against the interpretation of this change as evidence for a discontinuity.

I have proposed earlier that coexisting conservative royal onomastics and innovations in the pantheon's structure in the Middle Bronze Age at Ebla may be interpreted as an attempt of the 'new' (Amorite) leaders of Ebla to find a 'compromise of reconnecting with past local traditions (non-Amorite royal onomastics) while also engaging with something "foreign" to them (the worship of Ishtar) 12' (D’Andrea 2019a: 24, 26). However, this was possibly the result of a process of negotiation of identities that may have involved deeper aspects than mere opportunistic choices, rooted in the very same genesis of the 'second-generation states' of Syria (again borrowing the definition from Schwartz 2013b: 498). With all due differences between western and eastern Syrian contexts, the best explanation for this phenomenon can be drawn from Ristvet's analysis of the ways Amorite rulers in Upper Mesopotamia pieced together in one social fabric the remnants of a pre-existing urban component and tribal components of the same society under the umbrella of the new tribal state formations (Ristvet 2012: 37-39, 45-47). This model may offer a feasible explanation for the coexistent trends of continuity and discontinuity with the local EB IVA tradition at Ebla in the Middle Bronze Age tangible and intangible cultural traits. Likewise, I believe that it was the very same fact that the responsible of the regeneration at Ebla already during EB IVB were already based in a local segment of a much larger component present in a broad geographic belt (see Porter 2019) spanning the whole zone of uncertainty at the margins of the agricultural urban cores as defined by Wilkinson et al. (2014: 53-55, fig. 3) that we may define as Amorites. This very same fact may explain changes between EB IVA and EB IVB, continuity between EB IVB and MB I, and resilience at Ebla through the end of EB IVB and the Middle Bronze Age

\footnotetext{
${ }^{12}$ With respect to this, it would be more appropriate to refer not to the worship of Ishtar per se, as the goddess was mentioned in the 24 th century BC text, but rather to the making of Ishtar a polyadic and dynastic goddess.
} 
despite the destruction in-between thanks to a flexible, adaptable social structure, ensuring to each sub-component a general, broader sense of belonging despite local political autonomy. This might have been the force driving the regeneration of urbanization at Ebla during a mature EB IVB phase, with the new local leaders possibly backedup by those of the sites on the western edge of the Syrian steppe, from which they were socio-politically distinct, but to which they were socio-culturally akin (D'Andrea 2020c: 10; 2020d: 159). Likewise, this might have been the pivotal force of Ebla's resilience at the turn between EB IVB and MB I that ensured fast recovery and steady growth of the city and its community after the destruction in the late EB IVB phase. If these were the forces and the processes at work at the site, this might account for EB IVB-MB I continuity at Ebla as well as for the blend of local long-established traits going back to the EB IVA tradition and new innovative aspects borrowed from the regions to the east and typifying the Middle Bronze Age sociocultural milieu.

\section{ACKNOWLEDGEMENTS}

The author wishes to thank warmly Candida Felli for the very much appreciated invitation to take part in a round table in Florence in December 2019, where the ideas form which this paper has developed were presented and discussed. I also wish to thank deeply the directors of the MAIS, Paolo Matthiae and Frances Pinnock, for allowing me to publish materials from Ebla in this article, and for helpful comments on the manuscript and the topics dealt herein.

\section{BIBLIOGRAPHY}

Akkermans P., M., M., G., Schwartz G.M., 2003, The Archaeology of Syria. From Complex Hunter-Gatherers to Early Urban Societies (ca. 16,000-300 BC), Cambridge, Cambridge University Press.

Alkhalid, M. 2014-15, The Begninning of the Middle Bronze Age, the Ebla Sequence and the Regional Periodisation, in P. Matthiae, M. Abdulkarim, F. Pinnock, M. Alkhalid (eds), Studies on the Archaeology of Ebla after 50 Years of Discoveries, Annales Archéologiques Arabes Syriennes 57-58: 165-179.

Alkhalid, M. 2018, One Hundred Years of Change at Ebla. The Pottery Assemblages between the $3^{\text {rd }}$ and the $2^{\text {nd }}$ Millennium BC, in P. Matthiae, F. Pinnock, M. D’Andrea (eds), Ebla and Beyond. Ancient Near Eastern Studies after Fifty Years of Discoveries at Tell Mardikh. Proceedings of the International Congress Held in Rome, 15th17th December 2014, Wiesbaden, Harrassowitz Verlag: 257-281.

Archi A. 2002, Formation of the west Hurrian Pantheon: the case of Išhara, in K. Asslan Yener, H. Hoffner Jr (eds), Recent Developments in Hittite Archaeology and History. Papers in Memory of Hans G. Güterbock, Eisenbrauns, Winona Lake, IN: 2l-33.

Archi A. 2015, Syria and Mesopotamia before the Akkadian Dynasty: Geopolitical Relations, in A. Archi, Ebla and Its Archives. Texts, History and Society, Studies in Ancient Near Eastern Records 7, Boston - Berlin, De Gruyter: 3-12.

Archi A., Biga M.G. 2003, A Victory over Mari and the Fall of Ebla, Journal of Cuneiform Studies 55: 1-44.

Baffi Guardata F. 2000, Le tombes du Bronze Moyen dans le secteur des fortifications à Ebla, in P. Matthiae, A. Enea, L. Peyronel, F. Pinnock (eds.), Proceedings of the First International Congress on the Archaeology of the Ancient Near East, Rome, May 18th-23rd 1998, Volume I. Roma, Università degli Studi di Roma «La Sapienza »: 35-78.

Biga M.G. 2013, Defining the Chora of Ebla. A Textual Perspective, in P. Matthiae, N. Marchetti, (eds.), Ebla and Its Landscape. Early State Formation in the Ancient Near East, Walnut Creek, CA, Left Coast Press: 259-267.

Biga M.G. 2014, The Syrian Steppes and the Kingdom of Ibal in the Third Millennium B.C.: New Data from the Ebla Texts, in D. Morandi Bonacossi (ed.), Settlement Dynamics and Human-Landscape Interaction in the Dry Steppes of Syria, (Studia Chaburensia 4), Wiesbaden, Harrassowitz Verlag: 199-208. 
Bonechi M. 1997, II Millennium Ebla Kings, Revue d'Assyriologie 91: 33-38.

Bonechi M., 2016. Thorny Geopolitical Problems in the Palace G Archives. The Ebla Southern Horizon, Part One: The Middle Orontes Basin, in D. Parayre, Le fleuve rebelle. Géographie historique du moyen Oronte d'Ebla à l'époque médiévale. Actes du colloque international tenu les 13 et 14 décembre 2012 à Nanterre (MAE) et à Paris (INHA), (Syria Supplément IV), Beyrouth, IPFO: 29-87.

Burke A.A. 2014a, Entanglement, the Amorite Koiné, and Amorite Cultures in the Levant, ARAM 26: 357-373.

Burke A.A. 2014b, Introduction to the Middle Bronze Age: Themes and Developments, in Steiner, M.L., Killebrew, A.E. (eds.), The Oxford Handbook of the Archaeology of the Levant: c. 8000-332 BCE, Oxford, Oxford University Press: 403-413.

Burke A.A. 2017 Amorites, Climate Change and the Negotiation of Identity at the End of the Third Millennium B.C., in F. Höflmayer (ed.), The Late Third Millennium in the Ancient Near East: Chronology, C14, and Climate Change, (Oriental Institute Seminars 11), Chicago, The Oriental Institute of the University of Chicago: 261-310.

Calcagnile L., Quart, G., D’Elia M. 2013, Just at That Time: ${ }^{14}$ C Determinations and Analyses from EB IVA Layers, in P. Matthiae, N. Marchetti (eds.), Ebla and Its Landscape. Early State Formation in the Ancient Near East, Walnut Creek, CA, Left Coast Press: 415-424.

Castel C, 2010, The First Temples in antis. The Sanctuary of Tell Al-Rawda in the Context of $3^{\text {rd }}$ Millennium Syria, in Becker, J. Hempelmann, R. Rehm, E. (eds), Kulturlandschaft Syrien, Zentrum und Peripherie, Festschrift für Jan-Waalke Meyer, (Alter Orient und Altes Testament 371), Münster, Ugarit-Verlag: 123-164.

Castel C. 2020, Syrian cities of the Third Millennium BC: A Syrian Urban Model, in C. Castel, J.-W. Meyer, P. Quenet (eds), Circular Cities of Early Bronze Age Syria, (Subartu LXII), Turnhout, Brepols: 3-23.

Catagnoti A. 1997, Sul lessico dei giuramenti a Ebla: nam-ku ${ }_{5}$, Miscellanea Eblaitica 4: 111-137.

Catagnoti A. 2020, The Ebla Palace G Texts and the Circular Cities of Third-Millennium Southern Syria: Some Remarks, in C. Castel, J.-W. Meyer, P. Quenet (eds), Circular Cities of Early Bronze Age Syria, (Subartu LXII), Turnhout, Brepols: 231-238.

Cooper L. 2006, Early Urbanism on the Syrian Euphrates, Oxon - New York.

Cooper L. 2014, The Northern Levant (Syria) during the Early Bronze Age, in M.L. Steiner, A.E. Killebrew (eds), The Oxford Handbook of the Archaeology of the Levant: c. 8000-332 BCE, Oxford, Oxford University Press: 278-290.

D’Andrea M. 2014-15, Early Bronze IVB at Ebla: Stratigraphy, Chronology, and Material Culture of the Late Early Syrian Town and Their Meaning in the Regional Context, in P. Matthiae, M. Abdulkarim, F. Pinnock, M. Alkhalid (eds), Studies on the Archaeology of Ebla after 50 Years of Discoveries, (Annales Archéologiques Arabes Syriennes 57-58), Damas, Ministére de la Culture, Direction Générale des Antquités: 131-164.

D’Andrea M. 2015, Preliminary Notes on Some EB IVB Painted Simple Ware Shards from Ebla, Studia Eblaitica 1: 205-209.

D’Andrea M. 2016a, New Data from Old Excavations: Preliminary Study of the EB IVB Pottery from Area $\mathrm{H}$ at Tell Mardikh/Ebla, Syria, in O. Kaelin, H.-P. Mathys (eds), Proceedings of the 9th International Conference on the Archaeology of the Ancient Near East, 8-14 June 2014 Basel, Volume 3, Wiesbaden, Harrassowitz Verlag: $199-216$

D’Andrea M. 2016b, Review of Recensione a Uwe Finkbeiner, Mirko Novák, Ferhan Sakal and Paola Sconzo (eds), ARCANE, Vol. IV: Middle Euphrates, Brepols Publishers, Turnhout, Belgium 2015, Studia Eblaitica 2: 213-223.

D’Andrea M. 2018, The Early Bronze IVB Pottery of Ebla: Stratigraphy, Chronology, Typology and Style, in P. Matthiae, F. Pinnock, M. D'Andrea (eds), Ebla and Beyond. Ancient Near Eastern Studies after Fifty Years of Discoveries at Tell Mardikh. Proceedings of the International Congress Held in Rome, 15th-17th December 2014, Wiesbaden, Harrassowitz Verlag: 221-255.

D’Andrea M. 2019a, Before the Cultural Koinè: Contextualizing Interculturality in the 'Greater Levant' during the Late Early Bronze Age and the Early Middle Bronze Age, in M. Bietak, S. Prell (eds), The Enigma of the Hyksos 
volume. I, ASOR Conference Boston 2017 - ICAANE Conference Munich 2018 - Collected Papers, (Contributions to the Archaeology of Egypt, Nubia and the Levant 9), Wiesbaden, Harrassowitz Verlag: 13-45.

D'Andrea M. 2019b, The EB-MB Transition at Ebla: A State-of-the-Art Overview in the Light of the 2004-2008 Discoveries at Tell Mardikh, in M. D’Andrea, M.G. Micale, D. Nadali, S. Pizzimenti, A. Vacca (eds), Pearls of the Past. Studies on Near Eastern Art and Archaeology in Honour of Frances Pinnock, (marru: Studien zur Vorderasiatischen Archäologie/Studies in Near and Middle Eastern Archaeology 8), Münster, Zaphon: 63-97.

D’Andrea M. 2020a, The Early Bronze IVB pottery from Tell Mardikh/Ebla. Chrono-typological and technological data for framing the site within the regional context, Levant 52(1-2), 56-84, DOI: 10.1080/00758914.2018.1449374.

D’Andrea M. 2020b, Ebla and the South: Reconsidering Inter-Regional Connections during Early Bronze IV, in M. Iamoni (ed.), Broadening Horizons 5. Civilizations in Contact. Volume I. From the Prehistory of Upper Mesopotamia to the Bronze Age Societies of the Levant. (West \& East. Monografie 2), Trieste: 201-222. Available online: http://hdl.handle.net/10077/30213.

D’Andrea M. 2020c, Some Thoughts on Early Bronze Age Religious Complexes at Megiddo and Khirbet ezZeraqon and Interregional Connections, Studia Eblaitica 6: 1-39.

D'Andrea M. 2020d, Again on the "Grey Wares", Ebla, the Steppe, and the South during Early Bronze IV, in Studia Eblaitica 6: 153-161.

D’Andrea M. 2021, Developing Connections and Changing Clusters: The Levant between c. 2600 and 1900 BCE, in M. Bietak, S. Prell (eds), The Enigma of the Hyksos Volume IV. Changing Clusters and Migration in the Near Eastern Bronze Age. Collected Papers of a Workshop held in Vienna $4^{\text {th }}-6^{\text {th }}$ of December 2019, (Contributions to the Archaeology of Egypt, Nubia and the Levant 12), Wiesbaden, Harrassowitz Verlag: 31-81.

Decker K., Drechsler P., Sconzo P. 2015, Radiocarbon Chronology, in U. Finkebeiner, M. Novák, F. Sakal, P. Sconzo (eds), Associated Regional Chronologies for the Ancient Near East and the Eastern Mediterranean IV: Middle Euphrates, Turnhout, Brepols: 401-422.

Dolce R. 1999, The "Second Ebla". A View on the EBIVB City, in ISIMU 2: 293-304.

Dolce R. 2001, Ebla after “The Fall”. Some Preliminary Considerations on EBIVB City, Damaszener Mitteilungen 13 (= Festschrift A Abu Assaf): 11-28.

Dolce R. 2002, Ebla et ses souverains. Du renouvellement de la ville protosyrienne tardive a l'epanouissement du regne amorreheen, in S. de Martino, F. Pecchioli Daddi (eds), Anatolia Antica. Studi in memoria di Fiorella Imparati, Tomo I, Firenze, LoGisma Editore: 211-238.

Dolce R. 2007, Du Bronze Ancien IVB au Bronze Moyen a Ebla - Limites et problemes pour une definition chronologique relative pendant la periode de la ville protosyrienne recent, in P. Matthiae, F. Pinnock, L. Nigro, L. Peyronel (eds), Atti del Convegno Internazionale "From Relative Chronology to Absolute Chronology: The 2nd Millenium BC in Syria-Palestine", Roma, 29 nov.-1 dec. 2001, Accademia Nazionale dei Lincei, (Contributi del Centro Linceo Interdisciplinare «Beniamino Segre» 117), Roma, Bardi: 171-194.

Dolce R. 2009, The Archaeology of a Long Lasting Power: the Ebla Paradigm. A Synthesis, Studi Micenei ed EgeoAnatolici 51: 251-278

Durand J.-M. 2012, Sargon a-t-il détruit la ville de Mari?, Revue d'Assyriologie 106 (= Recueil d'études historiques, philologiques et épigraphiques en l'honneur de Paolo Matthiae): 117-131.

Falconer S.E., Fall P.L. 2006, Bronze Age Rural Economy and Village Life at Tell el-Hayyat, Jordan, (British Archaeological Reports - International Series 1586), Oxford, Archaeopress.

Felli C., Merluzzi E. 2008, EB-MB Afis: A Single Cultural Tradition between Two Phases?, H. Kühne, R.M. Czichon, J. Kreppner (eds), Proceedings of the 4th International Congress of the Archaeology of the Ancient Near East: 29 March-3 April, Freie Universität Berlin, Vol. 2, Wiesbaden, Harrassowitz Verlag: 97-110.

Finkbeiner U., Novák M., 2015, Introduction, in U. Finkebeiner, M. Novák, F. Sakal, P. Sconzo (eds), Associated Regional Chronologies for the Ancient Near East and the Eastern Mediterranean IV: Middle Euphrates, Turnhout, Brepols: 1-16. 
Fiorentino G., Caracuta V., Calcagnile L., D’Elia M., Matthiae P., Mavelli F., Quarta G. 2008, Third Millennium B.C. Climate Change in Syria Highlighted by Carbon Stable Isotope Analysis of ${ }^{14} \mathrm{C}$-AMS Dated Plant Remains from Ebla, Palaeogeography, Palaeoclimatology, Palaeoecology 266: 51-58.

Floriani Squarciapino M. 1967, Il settore D, in A. Davico, M. Floriani Squarciapino, P. Fronzaroli, M. Liverani, P. Matthiae, G. Scandone Matthiae, Missione Archeologica Italiana in Siria. Rapporto Preliminare della Campagna 1966, Roma, Istituto di Studi del Vicino Oriente - Università: 63-77.

Frayne D.R. 1990, Old Babylonian Period (2003-1595 B.C.). Royal Inscriptions of Mesopotamia: Early Periods, vol. 4, Toronto, University of Toronto Press.

Fronzaroli P. 1967, Il settore E, in A. Davico, M. Floriani Squarciapino, P. Fronzaroli, M. Liverani, P. Matthiae, G. Scandone Matthiae, Missione Archeologica Italiana in Siria. Rapporto Preliminare della Campagna 1966, (Serie Archeologica 13), Roma, Istituto di Studi del Vicino Oriente: 79-110.

Fronzaroli P. 2003, Archivi Reali di Ebla, Testi XIII. I Testi di Cancelleria: I Rapporti con le Città (Archivio L.2769), Università degli Studi di Roma "La Sapienza”.

Gelb I.J 1984, The Inscription of Jibbit-Lim, King of Ebla, Studia Orientalia LV: 213-229.

Homsher R.S., Cradic M. 2017, The Amorite Problem: Resolving an Historical Dilemma, Levant 49/3: 259-283. DOI: https://doi.org/10.1080/00758914.2017.1418038.

Homsher R.S., Cradic M. 2018, Rethinking Amorites, in O. Lipschits, Y. Gadot, M.J. Adams (eds), Rethinking Israel: Studies in the History and Archaeology of Ancient Israel in Honor of Israel Finkelstein, Winona Lake, IN, Eisenbrauns: 131-150.

Iamoni M. 2014, Transitions in Ceramics, a Critical Account and Suggested Approach: Case-Study through Comparison of the EBA-MBA and MBA-LB Horizons at Qatna, Levant 46/1: 4-26. DOI: https://doi.org/10.117 9/0075891413Z.00000000028.

Kennedy M.A. 2015, The Late Third Millennium BCE in the Upper Orontes Valley, Syria: Ceramics, Chronology and Cultural Connections, (Ancient Near Eastern Studies Supplementary Series 46), Leuven, Peeters.

Kennedy M.A. 2016, The End of the $3^{\text {rd }}$ Millennium BC in the Levant: New Perspectives and Old Ideas, Levant 48/1: 1-32. DOI: https://doi.org/10.1080/00758914.2016.1143750.

Koliński R. 2014, 20 ${ }^{\text {th }}$ Century B.C. in the Khabur Triangle Region and the Advent of the Old Assyrian Trade with Anatolia, in D. Bonatz (eds), The Archaeology of Political Spaces: The Upper Mesopotamian Piedmont in the Second Millennium B.C.E., (TOPOI Berlin Studies of the Ancient World 12). Berlin, De Gruyter: 11-34.

Manning S., Barjamovic G., Lorentzen B. 2017, The Course of C14 Dating Does Not Run Smooth: Tree-Rings, Radiocarbon, and Potential Impacts of a Calibration Curve Wiggle on Dating Mesopotamian Chronology, Journal of Ancient Egyptian Interconnections 13: 70-81.

Matthiae P. 1993, L'aire sacrée d'Ishtar à Ebla : résultats des fouilles de 1990-1992, Comptes rendus des séances de l'Académie des Inscriptions et Belles-Lettres 137/3: 613-662.

Matthiae P. 1995, Fouilles à Ébla en 1993-1994 : les palais de la ville basse nord, Comptes rendus des séances de l'Académie des Inscriptions et Belles-Lettres 139/2: 651-681.

Matthiae P. 2003, Ishtar of Ebla and Hadad of Aleppo: Notes on Terminology, Politics and Religion of Old Syrian Ebla, in P. Marrassini (ed.), Semitic and Assyriological Studies Presented to P. Fronzaroli by Pupils and Colleagues, Wiesbaden, Harrassowitz Verlag: 381-402.

Matthiae P. 2006a, Un grand temple de l'époque des Archives dans l'Ebla protosyrienne: Fouilles à Tell Mardikh 2004-2005, Comptes rendus des séances de l’Académie des Inscriptions et Belles-Lettres 150: 447-493.

Matthiae P. 2006b, The Archaic Palace at Ebla: A Royal Building between Early Bronze Age IVB and Middle Bronze Age I, in S. Gitin, J.E. Wright, J.P Dessel (eds), Confronting the Past. Archaeological and Historical Essays on Ancient Israel in Honor of William G. Dever, Winona Lake, IN, Eisenbrauns: 85-103.

Matthiae P. 2007, Nouvelle fouilles à Ébla en 2006: le temple du Rocher et ses successeurs protosyriens et paléosyriens, Comptes rendus des séances de l'Académie des Inscriptions et Belles-Lettres 151/1: 481-525.

Matthiae P. 2009a, Temples et reines de l'Ébla Protosyrienne: Résultats de fouilles à Tell Mardikh en 2007 et 2008, Comptes rendus des séances de l'Académie des Inscriptions et Belles-Lettres 153: 747-791. 
Matthiae P. 2009b, Crisis and Collapse: Similarity and Diversity in the Three Destructions of Ebla from EB IVA to MB II, Scienze dell'Antichità 15: 165-204.

Matthiae P. 2010, Ebla la città del trono. Archeologia e storia, (Piccola Biblioteca Einaudi 492), Torino, Einaudi.

Matthiae P. 2013a, The Archaic Palace at Ebla: A Royal Building between Early Bronze Age IVB and Middle Bronze Age I, in P. Matthiae, Studies on the Archaeology of Ebla 1980-2010, edited by Frances Pinnock, Wiesbaden, Harassowitz Verlag: 242-257.

Matthiae P. 2013b, Crisis and collapse: similarity and diversity in the three destructions of Ebla from EB IVA to MB II, in P. Matthiae, Studies on the Archaeology of Ebla 1980-2010, edited by Frances Pinnock, Wiesbaden, Harassowitz Verlag: 57-94.

Matthiae P. 2020, The Problem of the Ebla Destruction and the End of Early Bronze IVB: Stratigraphic Evidence Historical Events, Radiocarbon Datings, in S. Richard (ed.), New Horizons in the Study of Early Bronze III and Early Bronze IV, University Park, Penn State University Press: 91-110.

Matthiae P. 2021, Ebla. Archaeology and History, (Cities of the Ancient World), Oxon - New York.

Matthiae P., Pinnock F., Scandone Matthiae G. (eds), 1995, Ebla. Alle origini della Civiltà Urbana in Siria, Electa, Milano.

Mazzoni S. 1985, Elements of the Ceramic Culture of Early Syrian Ebla in Comparison with Syro-Palestinian EB IV, Bulletin of the American Schools of Oriental Research 257: 1-18.

Mazzoni S. 2002, The Ancient Bronze Age Pottery Tradition in Northwestern Central Syria, in M. Al-Maqdissi, V. Matoïan, C. Nicolle (eds), Céramique de l’Âge du Bronze en Syrie I, (Bibliothèque Archéologique et Historique 161), Beyrouth, IFPO: 69-96.

Mazzoni S. 2013, Tell Afis and the Early-Middle Bronze Age Transition, in: S. Mazzoni, S. Soldi (eds), Syrian Archaeology in Perspective: Celebrating 20 Years of Excavations at Tell Afis. Proceedings of the International Meeting Percorsi di Archeologia Siriana Giornate di Studio Pisa 27-28 Novembre 2006 Gipsoteca di Arte Antica - S. Paolo all'Orto, Pisa, Edizioni ETS: 31-80.

Mazzoni S., Felli C. 2007, Bridging the $3^{\text {rd }} / 2^{\text {nd }}$ Millennium Divide: The Afis and Ebla Evidence, in C. Kuzucuoğlu, C. Marro (eds), Sociétés humaines et changement climatique à la fin du troisième millénaire: une crise a-t-elle eu lieu en Haute Mésopotamie?, (Varia Anatolica 19), Paris, De Boccard: 205-224.

Mebert J. 2010, Die Venustafeln des Ammi-saduqa und ibre Bedeutung für die astronomische Datierung der altbabylonischen Zeit, (Archiv für Orientforschung, Beiheft 31), Wien, Institut für Orientalistik der Universität Wien.

Morandi Bonacossi D. 2008, The EB/MB Transition at Tell Mishrifeh: Stratigraphy, Ceramics and Absolute Chronology: A Preliminary Review, in M. Bietak, E. Czerny (eds), The Bronze Age in the Lebanon: Studies on the Archaeology and Chronology of Lebanon, Syria, and Egypt, (Contributions to the Chronology of the Eastern Mediterranean 17), Vienna, Verlag der Österreichischen Akademie des Wissenschaften: 127-152.

Morandi Bonacossi D. 2009, Tell Mishrifeh and Its Region during the EBA IV and the EBA-MBA Transition: A First Assessment, in P.J. Parr (ed.), The Levant in Transition: Proceedings of a Conference Held at the British Museum on 20-21 April 2004, (Palestine Exploration Fund Annuals 9), Leeds, Maney: 56-68.

Morandi Bonacossi D. 2011, The Middle Bronze Age Necropolis at Mishrifeh, in P. Pfälzner (ed.), Interdisziplinäre Studien zur Königsgruft von Qatna, (Qatna-Studien 1), Wiesbaden, Harrassowitz Verlag: 11-37.

Morandi Bonacossi D. 2014, The Northern Levant (Syria) in the Middle Bronze Age, in M.L. Steiner, A.E. Killebrew (eds.), The Oxford Handbook of the Archaeology of the Levant: c. 8000-332 BCE, Oxford, Oxford University Press: 414-433.

Morandi Bonacossi D. 2016, Qatna, in Y. Kanjou, Y. Tsuneki (eds), A History of Syria in One Hundred Sites, Cambridge, Archaeopress: 151-155.

Mouamar G. 2020, A New Planned Major City on the Margins of the Syrian Steppe: Early Bronze Age Tell Shairat, in C. Castel, J.-W- Meyer, P. Quenet (eds), Circular Cities of Early Bronze Age Syria, (Subartu LXII), Turnhout, Brepols: 335-352.

Nadali D. 2018, Inward/Outward: A Re-Examination of the City-Gates at Ebla, in P. Matthiae, F. Pinnock, M. D'Andrea (eds), Ebla and Beyond. Ancient Near Eastern Studies after Fifty Years of Discoveries at Tell Mardikh. 
Proceedings of the International Congress Held in Rome, 15th-17th December 2014, Wiesbaden, Harrassowitz Verlag: 295-316.

Nichols J.J., Weber J.A. 2010, Amorites, Onagers, and Social Reorganization in Middle Bronze Age Syria, in G.M Schwartz, J.J. Nichols (eds), After Collapse. The Regeneration of Complex Societies, Tucson, The University of Arizona Press: $38-57$.

Nigro L. 2002, The Middle Bronze Age Pottery Horizon of Northern Inner Syria on the Basis of the Stratified Assemblages of Tell Mardikh and Hama, in M. Al-Maqdissi, V. Matoïan, C. Nicolle (eds), Céramique de l'Âge du Bronze en Syrie I, (Bibliothèque Archéologique et Historique 161), Beyrouth, IFPO: 97-128.

Nigro L. 2007, Towards a Unified Chronology of Syria and Palestine: The Beginning of the Middle Bronze Age, in P. Matthiae, F. Pinnock, L. Nigro, L. Peyronel (eds), Atti del Convegno Internazionale "From Relative Chronology to Absolute Chronology: The 2nd Millenium BC in Syria-Palestine", Roma, 29 nov.-1 dec. 2001, Accademia Nazionale dei Lincei, (Contributi del Centro Linceo Interdisciplinare «Beniamino Segre» 117), Roma, Bardi: 365-389.

Nigro L. 2009, Materiali e Studi Archeologici di Ebla VIII. I corredi vascolari delle tombe reali di Ebla e la cronologia ceramica della Siria interna nel Bronzo Medio, Roma, Sapienza Università di Roma.

Nishiyama S. 2009, Radiocarbon Dating, Tell Mastuma. An Iron Age Settlement in Northwest Syria, (Memoirs of the Ancient Orient Museum 3), Tokyo, Orient Museum: 520-528.

Oates D., Oates J., McDonald E. 1997, Excavations at Tell Brak. Volume I: The Mitanni and Old Babylonian Periods, Cambridge - London, McDonald Institute for Archaeological Research - British School of Archaeology in Iraq.

Orsi V. 2012, Tell Barri before Kahat, in H. Weiss (ed.), Seven Generations Since the Fall of Akkad, (Studia Chaburiensia 3), Wiesbaden, Harrassowitz Verlag: 89-108.

Owen D.E. 1992, Sumerian Sources from the Ur III Period, in M.W. Chavalas, J.L. Hayes (eds), New Horizons in the Study of Ancient Syria, (Bibliotheca Mesopotamica 25), Malibu, Undena: 108-175.

Peyronel L. 2014, Living Near the Lake. The Matkh Region (Syria) during the Early and Middle Bronze Ages, in F. Baff, R. Fiorentino, L. Peyronel (eds), Tell Tuqan Excavations and Regional Perspectives. Cultural Developments in Inner Syria from the Early Bronze Age to the Persian/Hellenistic Period. Proceedings of the International Conference May 15th-17th 2013, Galatina - Lecce, Congedo Editore: 115-161.

Peyronel L. 2019, The Beginning of the Middle Bronze Age in the Northern Levant. The Pottery from the EE Midden at Tell Mardikh-Ebla, Syria (c. 2000-1900 BC), in M. D’Andrea, M.G. Micale, D. Nadali, S. Pizzimenti, A. Vacca (eds), Pearls of the Past. Studies on Near Eastern Art and Archaeology in Honour of Frances Pinnock, (marru: Studien zur Vorderasiatischen Archäologie/Studies in Near and Middle Eastern Archaeology 8), Münster, Zaphon: 741-760.

Pfälzner P. 2017, Habur Ware and Social Continuity: The Chronology of the Early to the Middle Bronze Age Transition in the Syrian Jazireh, in F. Höflmayer (ed.), The Late Third Millennium in the Ancient Near East: Chronology, C14, and Climate Change, (Oriental Institute Seminars 11), Chicago, The Oriental Institute of the University of Chicago: 163-203.

Pinnock F. 2000, Some Thoughts about the Transmission of Iconographies between North Syria and Cappadocia, End of the Third-Beginning of the Second Millennium BC, in P. Matthiae, A. Enea, L. Peyronel, F. Pinnock (eds), Proceedings of the First International Congress on the Archaeology of the Ancient Near East, Rome, May 18th-23rd 1998, Volume II. Roma, Università degli Studi di Roma «La Sapienza»: 1397-1416.

Pinnock F. 2004, Change and continuity of art in Syria viewed from Ebla, in, J.-W. Mayer, W. Sommerfeld (eds), 2000 v.Chr - Politische, wirtschaftliche und kulturelle Entwicklung im Zeichen ein Jahrtausenwende. 3. Internationales Colloquium des Deutchen Orient-Gesellschaft 4-7 April 2000 in Frankfurt/Main und Marburg/Labn, Saarbrücken, Saarbrücker Druckerei und Verlag: 87-118.

Pinnock F. 2009, EB IVB-MB I in Northern Syria: Crisis and Change of a Mature Urban Civilisation, in P.J. Parr (ed.), The Levant in Transition: Proceedings of a Conference Held at the British Museum on 20-21 April 2004, (Palestine Exploration Fund Annuals 9), Leeds, Maney: 69-79. 
Porter A. 2007a, You say potato, I say... Typology, Chronology and the Origins of the Amorites, in C. Kuzucuoğlu, C. Marro (eds), Sociétés humaines et changement climatique à la fin du troisième millénaire: une crise a-t-elle eu lieu en Haute Mésopotamie?, (Varia Anatolica XIX), Paris: 69-115.

Porter A. 2007b, The ceramic assemblages of the third millennium in the Euphrates region, in M. Al-Maqdissi, V. Matoïan, C. Nicolle (eds), Céramique de l'Âge du Bronze en Syrie, II, L'Euphrate et la région de Jézireh, (Bibliothèque Archéologique et Historique 180), Beyrouth, IFPO: 3-22.

Porter A. 2012, Mobile Pastoralism and the Formation of Near Eastern Civilizations: Weaving Together Society, Cambridge, New York, Melbourne.

Porter A. 2019, Isotopes and Ideograms: Bio-archaeological and Theoretical Approaches to Pastoralism in Light of the Mari (and Other) Texts, Claroscuro 18.2: 1-34.

Pruß A. 2007, Comb-incised Pottery in Syria and Mesopotamia and its Relevance for Chronology, in P. Matthiae, F. Pinnock, L. Nigro, L. Peyronel (eds), Atti del Convegno Internazionale "From Relative Chronology to Absolute Chronology: The 2nd Millenium BC in Syria-Palestine", Roma, 29 nov.-1 dec. 2001, Accademia Nazionale dei Lincei, (Contributi del Centro Linceo Interdisciplinare «Beniamino Segre» 117), Roma, Bardi: 473-491.

Ristvet L. 2012, Resettling Apum: Tribalism and Tribal State in the Tell Leilan Region, Syria, in N. Laneri, P. Pfälzner, S. Valentini (eds), Looking North: The Socioeconomic Dynamics of the Northern Mesopotamian and Anatolian Regions during the Late Third and Early Second Millennium BC, (Studien zur Urbanisierung Nordmesopotamiens/D), Wiesbaden, Harrassowitz Verlag: 37-49.

Rova E. 2011, Ceramics, in M. Lebeau (ed.), Associated Regional Chronologies for the Ancient Near East and the Eastern Mediterranean I: Jezirah, Turnhout, Brepols: 49-127

Rousset M.-O., Geyer B., Shabo S., Awad N. 2017, Un réseau défensif de l'âge du Bronze moyen dans les Marges arides de Syrie du Nord, Paléorient 43/2: 115-163

Sallaberger W. 2007, From Urban Culture to Nomadism: A History of Upper Mesopotamia in the Late Third Millennium, in C. Kuzucuoğlu, C. Marro (eds), Sociétés humaines et changement climatique à la fin du troisième millénaire : une crise a-t-elle eu lieu en Haute Mésopotamie?, (Varia Anatolica XIX), Paris, De Boccard: 417456.

Sallaberger W., Shrakamp I. 2015, Associated Regional Chronologies for the Ancient Near East and the Eastern Mediterranean III: History and Philology, Turnhuot, Brepols.

Schmidt C. 2012, The Late Third and Early Second Millennium BC Pottery Tradition in the Syrian Jazirah and Beyond, in N. Laneri, P. Pfälzner, S. Valentini (eds), Looking North: The Socioeconomic Dynamics of the Northern Mesopotamian and Anatolian Regions during the Late Third and Early Second Millennium BC, (Studien zur Urbanisierung Nordmesopotamiens/D), Wiesbaden, Harrassowitz Verlag: 163-174.

Schmidt 2014, Late $3^{\text {rd }}$ Millennium “Ur III" Carinated Bowls, in M. Lebeau (ed.), Associated Regional Chronologies for the Ancient Near East and the Eastern Mediterranean Inter-regional I: Ceramics, Turnhuot, Brepols: 365 371.

Schwartz G.M. 2007, Taking the Long View on Collapse: A Syrian Perspective, in C. Kuzucuoğlu, C. Marro (eds), Sociétés humaines et changement climatique à la fin du troisième millénaire : une crise a-t-elle eu lieu en Haute Mésopotamie?, (Varia Anatolica XIX), Paris, De Boccard: 45-67.

Schwartz G.M. 2013a, An Amorite Global Village: Syrian-Mesopotamian Relations in the $2^{\text {nd }}$ Millennium BC, in J. Aruz, S. Graff, Y Rakic (eds), Cultures in Contact: From Mesopotamia to the Mediterranean in the Second Millennium $B C$, New Haven, Yale University Press: 2-11.

Schwartz G.M. 2013b, Memory and its Demolition: Ancestors, Animals and Sacrifice at Umm el-Marra, Syria, Cambridge Archaeological Journal 23/3: 495-522. DOI: https://doi.org/10.1017/S0959774313000504.

Schwartz G.M. 2017, Western Syria and the Third- to Second-Millennium BC Transition, in Höflmayer, F. (ed.), The Late Third Millennium in the Ancient Near East: Chronology, C14, and Climate Change, (Oriental Institute Seminars 11), Chicago, The Oriental Institute of the University of Chicago: 87-128.

Schwartz G.M., Miller N.F. 2007, The "Crisis" of the Late Third Millennium B.C.: Ecofactual and Arrtifactual Evidence from Umm el-Marra and the Jabbul Plain, in C. Kuzucuoğlu, C. Marro (eds), Sociétés humaines et 
changement climatique à la fin du troisième millénaire : une crise a-t-elle eu lieu en Haute Mésopotamie?, (Varia Anatolica XIX), Paris, De Boccard: 179-203.

Sconzo P. 2015, Ceramics, in U. Finkebeiner, M. Novák, F. Sakal, P. Sconzo (eds), Associated Regional Chronologies for the Ancient Near East and the Eastern Mediterranean IV: Middle Euphrates, Turnhout, Brepols: 95-203.

Skourtanioti E., Erdal Y.S., Frangipane M., Balossi Restelli F., Yener K.A., Pinnock F., Matthiae P., Özbal R., Schoop U.-D., Guliyev F., Akhundov T., Lyonnet B., Hammer E.L., Nugent S.E., Burri M., Neumann G.U., Penske S., Ingman T., Akar M., Shafiq R., Palumbi G., Eisenmann S., D’Andrea M., Rohrlach A.B., Warinner C., Jeong C., Stockhammer P.W., Haak W., Krause J. 2020, Genomic History of Neolithic to Bronze Age Anatolia, Northern Levant, and Southern Caucasus, Cell 181.5, 1158-1175. DOI: https://doi.org/10.1016/j. cell.2020.04.044.

Thalmann J-P. 2010, Tell Arqa: a Prosperous City in the Bronze Age, Near Eastern Archaeology 73.2-3: 86-101.

Weiss H. 2012, Quantifying Collapse: The Late Third Millennium BC Khabur Plain, in H. Weiss (ed.), Seven Generations Since the Fall of Akkad, (Studia Chaburiensia 3), Wiesbaden, Harrassowitz Verlag: 1-24.

Weiss H. 2014, The Northern Levant during the Intermediate Bronze Age: Altered Trajectories, in M. Steiner, A.E. Killebrew (eds.), The Oxford Handbook of the Archaeology of the Levant: c. 8000-332 BCE, Oxford, Oxford University Press: 367-387.

Weiss H. 2017, Seventeen Kings Who Lived in Tents, in F. Höflmayer (ed.), The Late Third Millennium in the Ancient Near East: Chronology, C14, and Climate Change, (Oriental Institute Seminars 11), Chicago, The Oriental Institute of the University of Chicago: 131-162.

Wilkinson T., Philip G., Bradbury J., Dunford R., Donoghue D., Galiatsatos N., Lawrence D., Ricci A., Smith S. 2014, Contextualizing Early Urbanization: Settlement Cores, Early States and Agro-pastoral Strategies in the Fertile Crescent during the Fourth and Third Millennia BC, Journal of World Prehistory 27: 43-109. DOI: https://doi.org/10.1007/s10963-014-9072-2. 


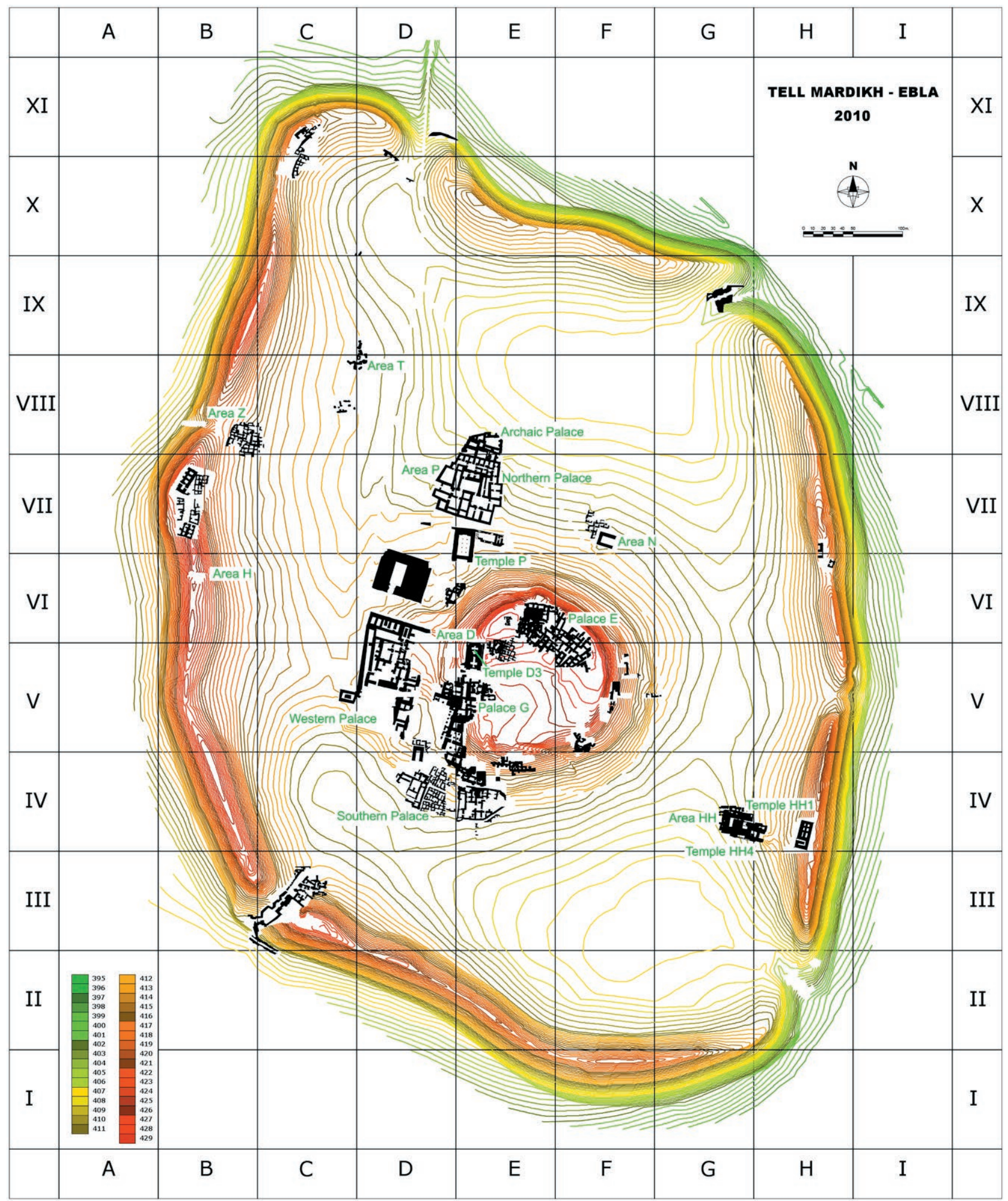

Fig. 1: Tell Mardikh/Ebla, topographical map captioned with areas and buildings mentioned in the text (๑ Missione Archeologica Italiana in Siria). 


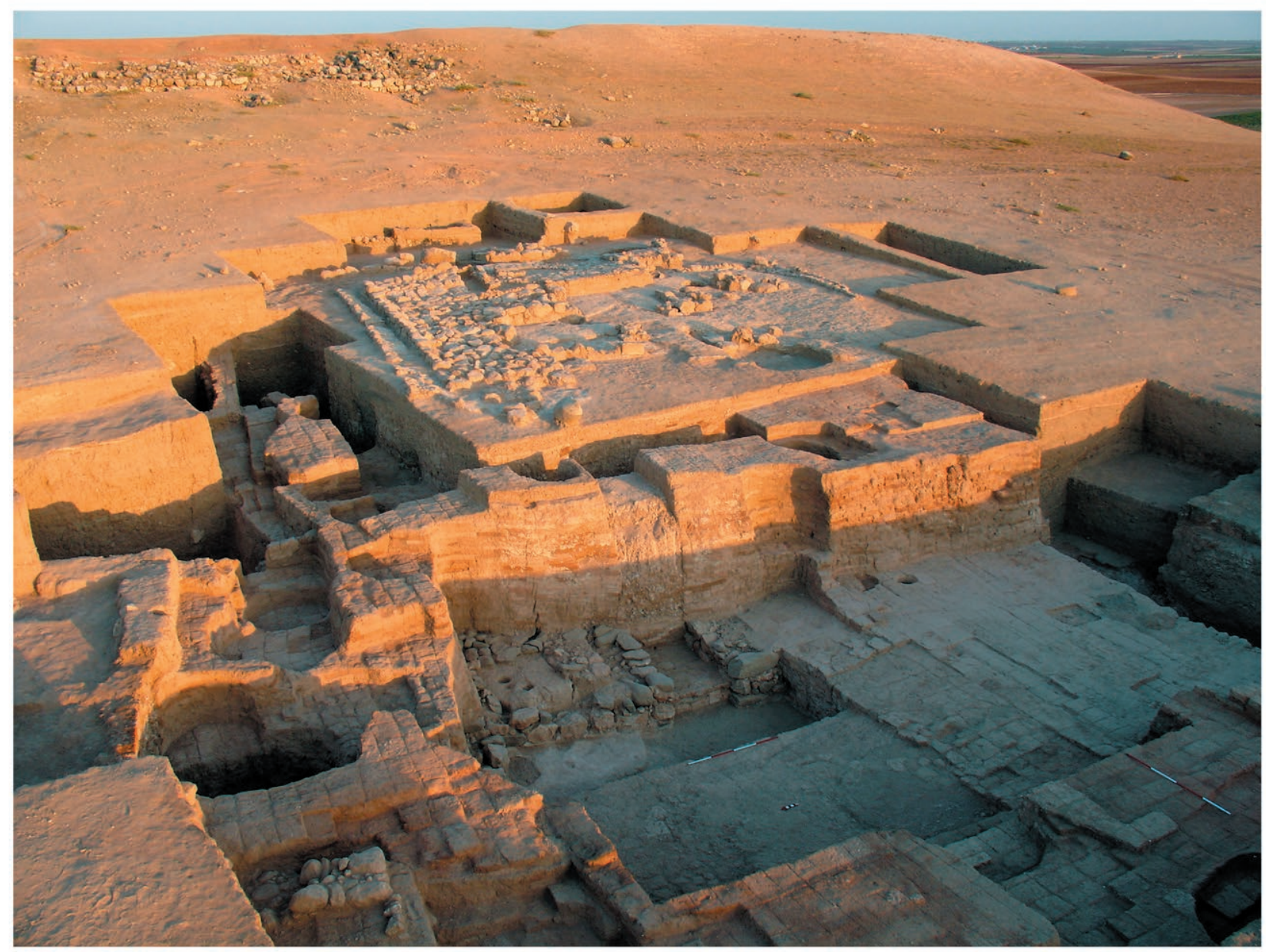

a

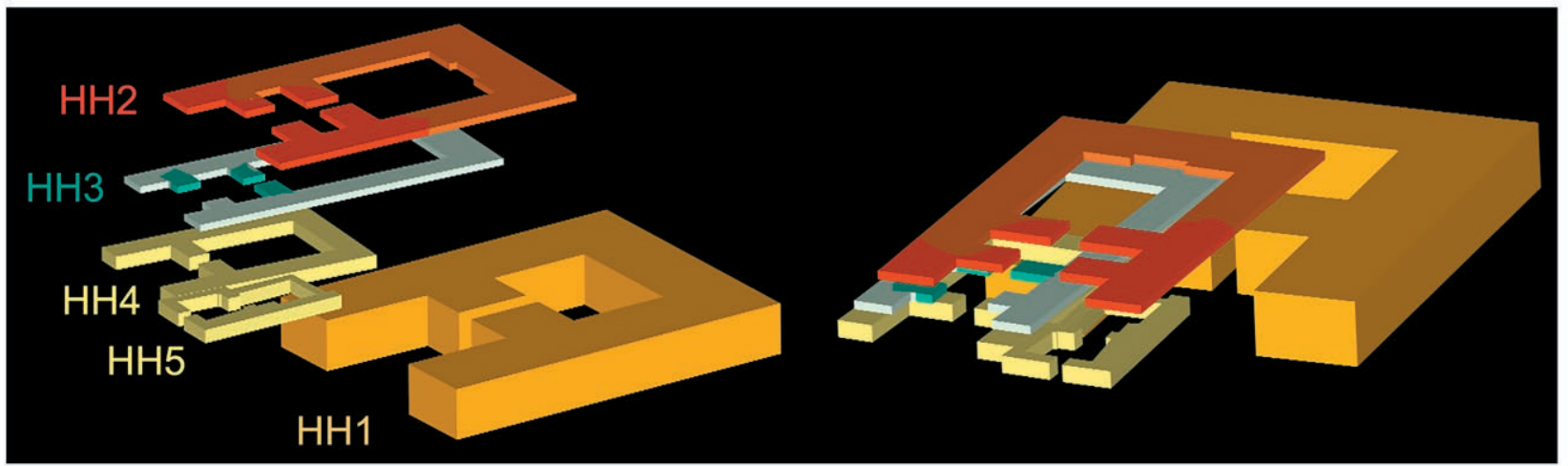

b

Fig. 2: Ebla, aerial view of Area HH (a), with the latest Middle Bronze Age temple in the background, the Early Bronze IVA Temple of the Rock in the foreground, and the latest Early Bronze IVB (EB IVB4) architecture on the left side (see enlarged view on Fig. 7), and schematic view (b) of the superimposed Early Bronze IVA, Early Bronze IVB, and Middle Bronze Age temples in antis (@ Missione Archeologica Italiana in Siria). 


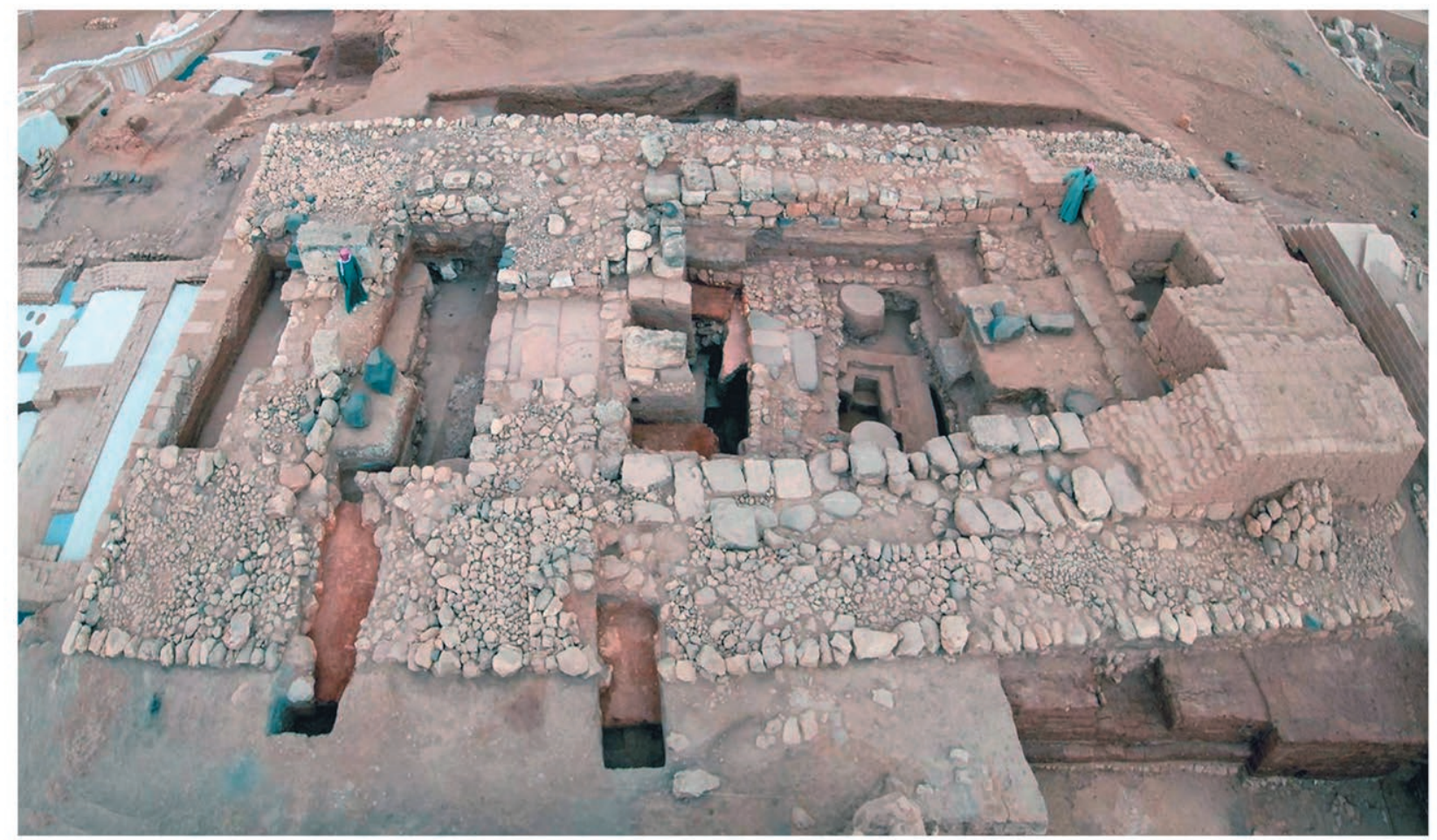

a

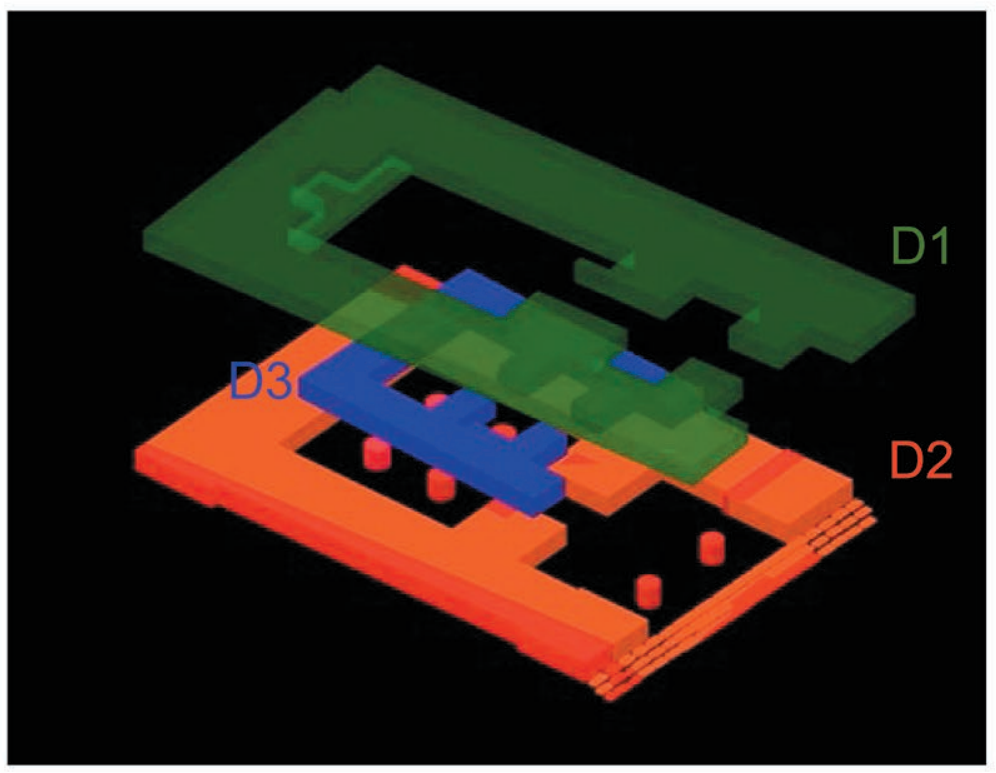

b

Fig. 3: Ebla, aerial view of Area D (a) and schematic view (b) of superimposed Early Bronze IVA, Early Bronze IVB, and Middle Bronze Age temples (๑ Missione Archeologica Italiana in Siria). 


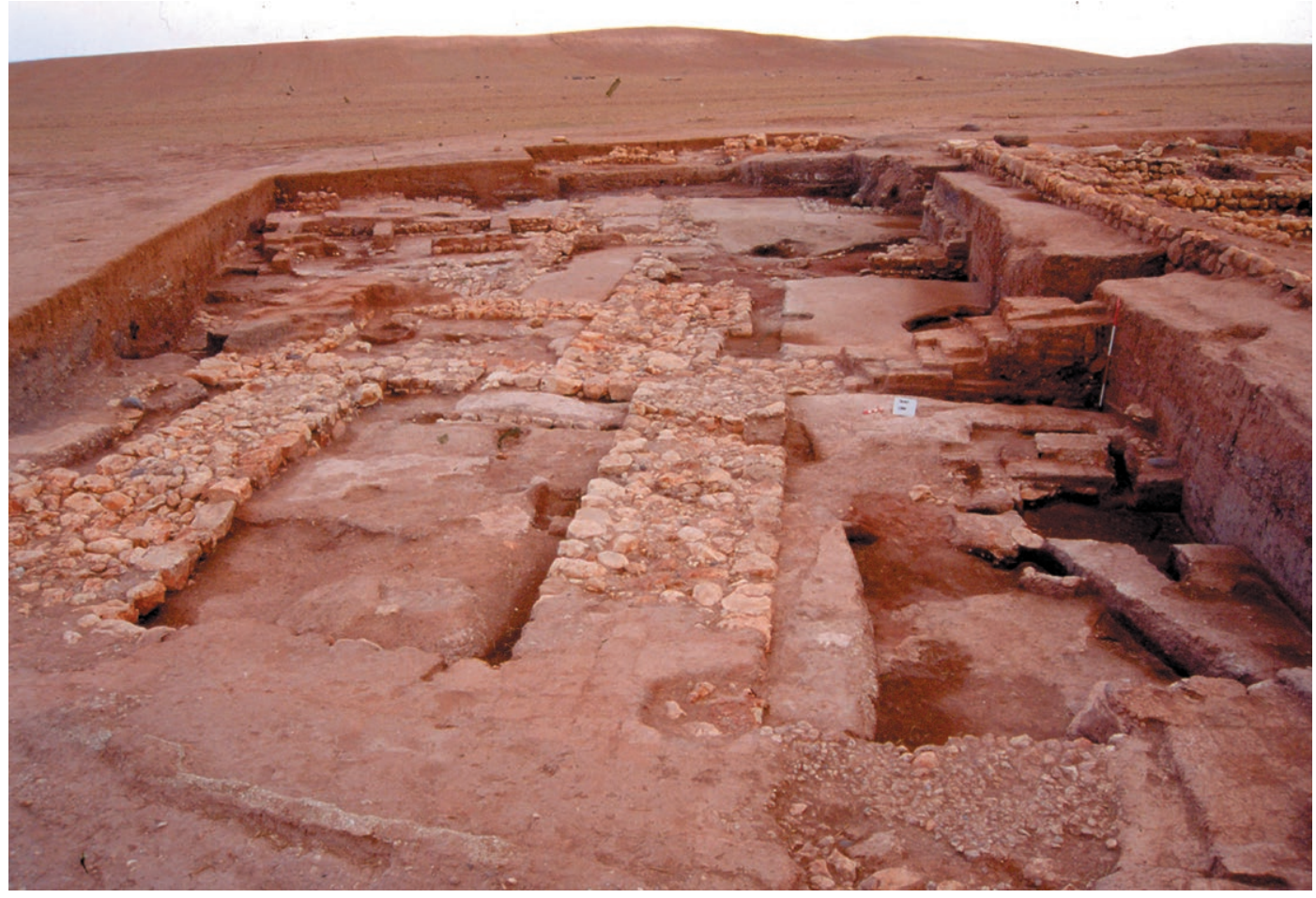

Fig. 4: Ebla, view of the Archaic Palace of EB IVB-MB I, with the ramparts in the background, looking east (@ Missione Archeologica Italiana in Siria).

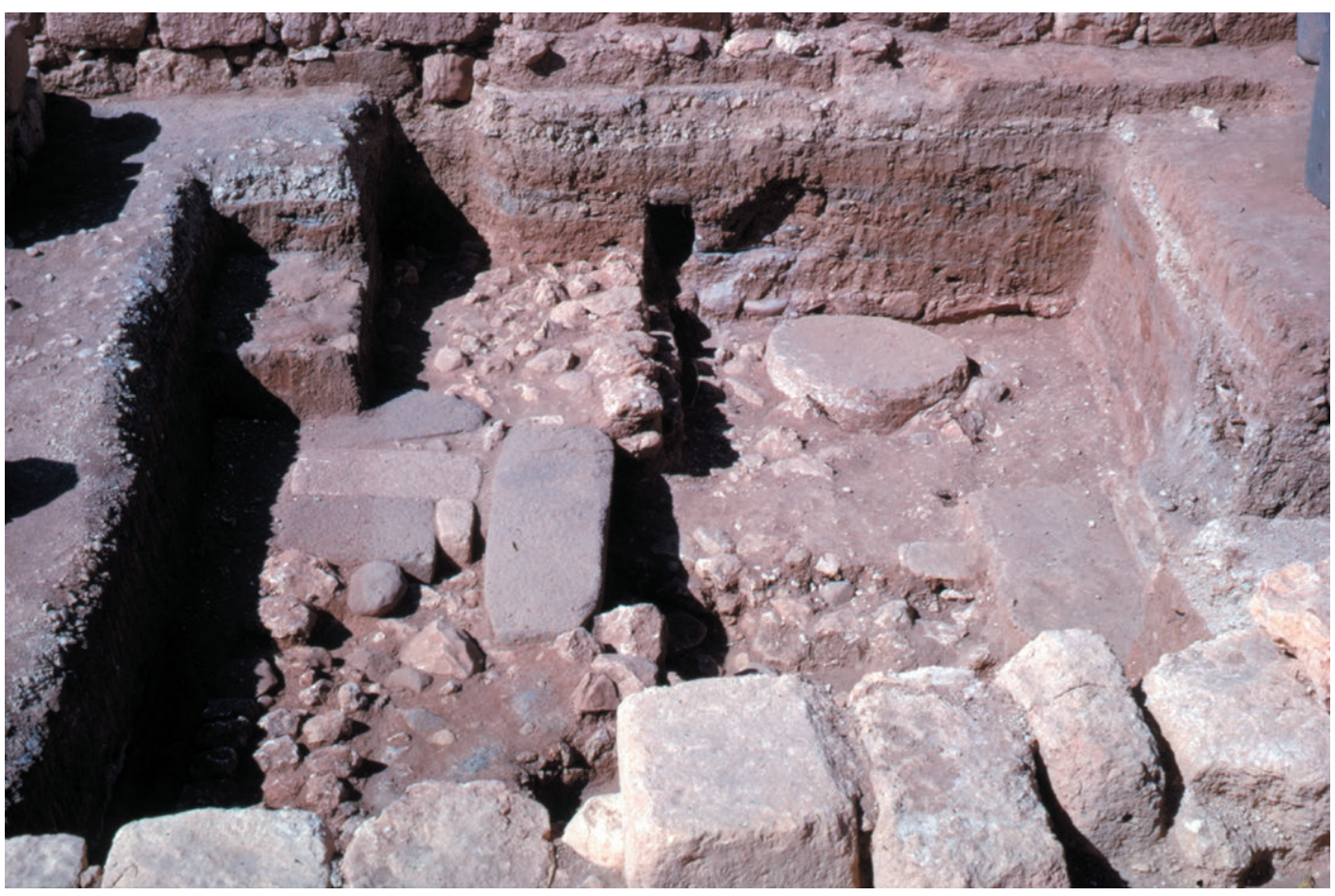

Fig. 5: Ebla, remains of Early Bronze IVB temple in the 1966 sondage enlarged in 1968 below the Middle Bronze Age Temple of Ishtar, looking west (๑ Missione Archeologica Italiana in Siria). 


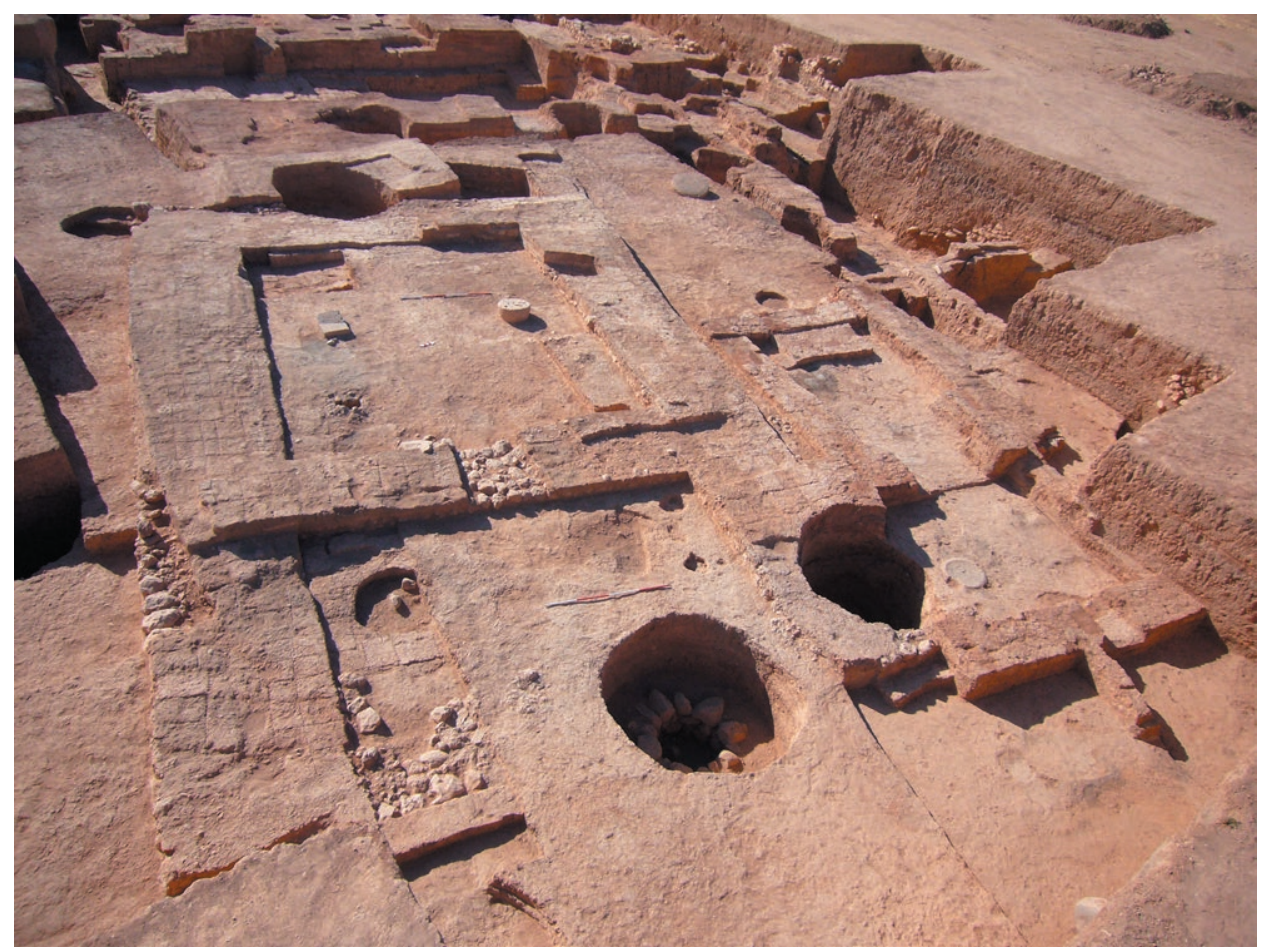

Fig. 6: Ebla, view of Early Bronze IVB Temple HH 4 and the smaller Temple HH5, looking north-west (@ Missione Archeologica Italiana in Siria).

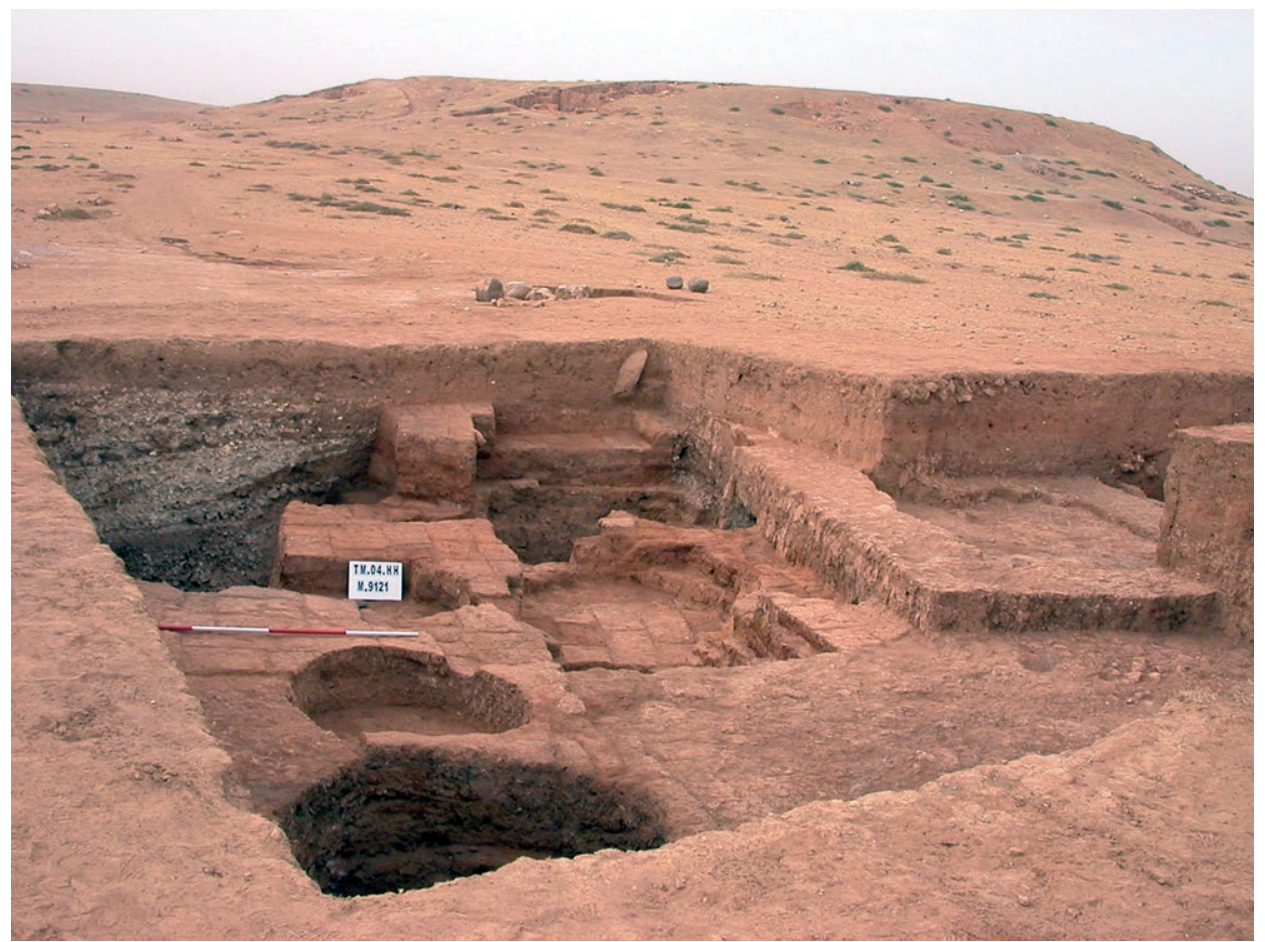

Fig. 7: Ebla, terminal Early Bronze IVB (EB IV4) occupation in Area HH (@ Missione Archeologica Italiana in Siria). 


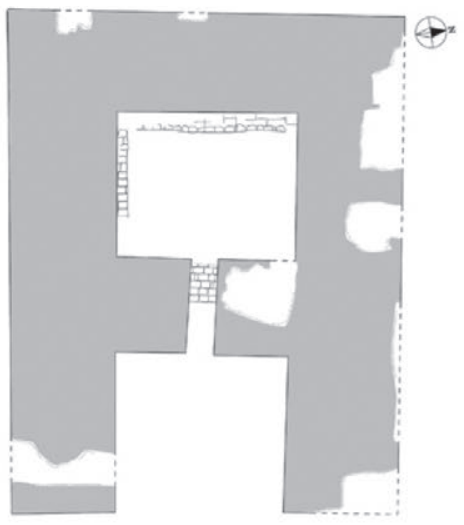

1

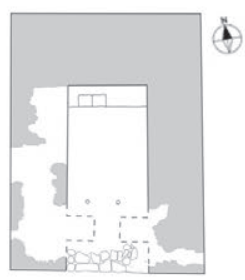

4

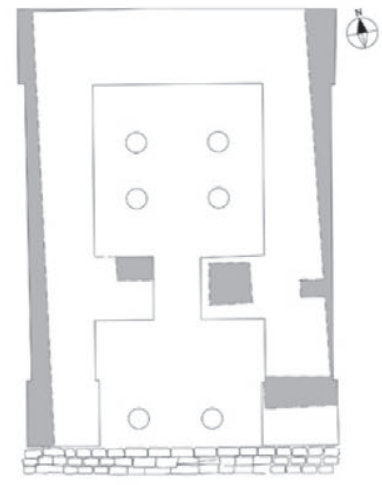

2

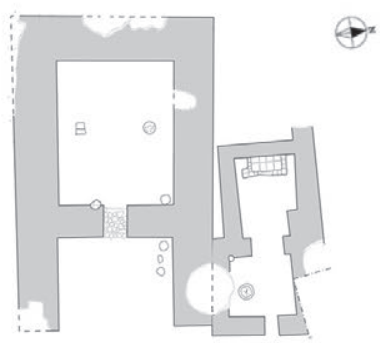

3

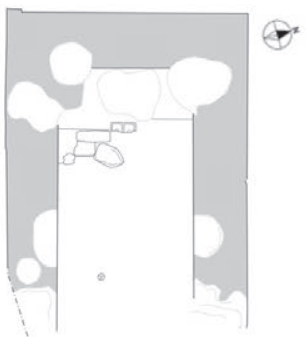

5

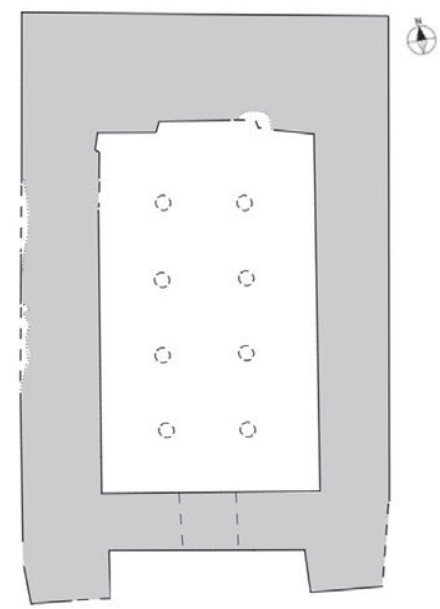

6

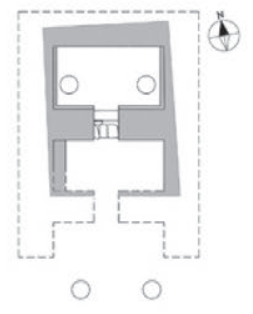

7

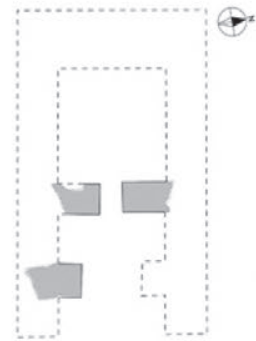

8

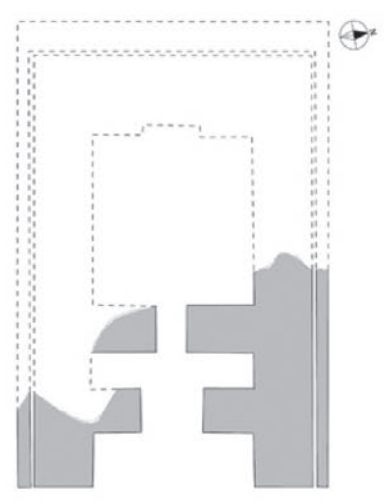

9

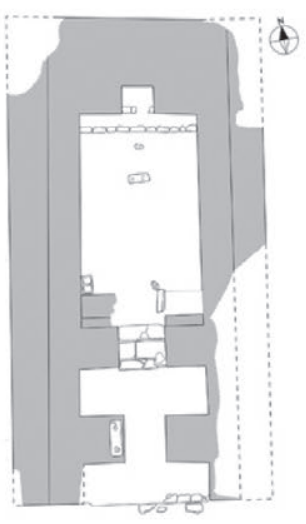

10

Fig. 8: Evolution of different types of temples in antis at Ebla from Early Bronze IVA to Middle Bronze II: bipartite (1-5), and tripartite (6-9) temples in antis: 1) Temple of the Rock (HH1), EB IVA; 2) Red Temple (D2), EB IVA; Temple HH4 (with minor shrine Temple HH5), EB IVB; 4) Temple B2 (Temple of Reshef), MB I-II; 5) Temple N (Temple of Shamash), MB I-II; 6) Temple P, MB I-II; 7) Temple D3, EB IVB; 8) Temple HH3, MB I; 9) Temple HH2, MB I-II; 10) Temple D (Temple of Ishtar), MB I-II (c) Missione Archeologica Italiana in Siria). 


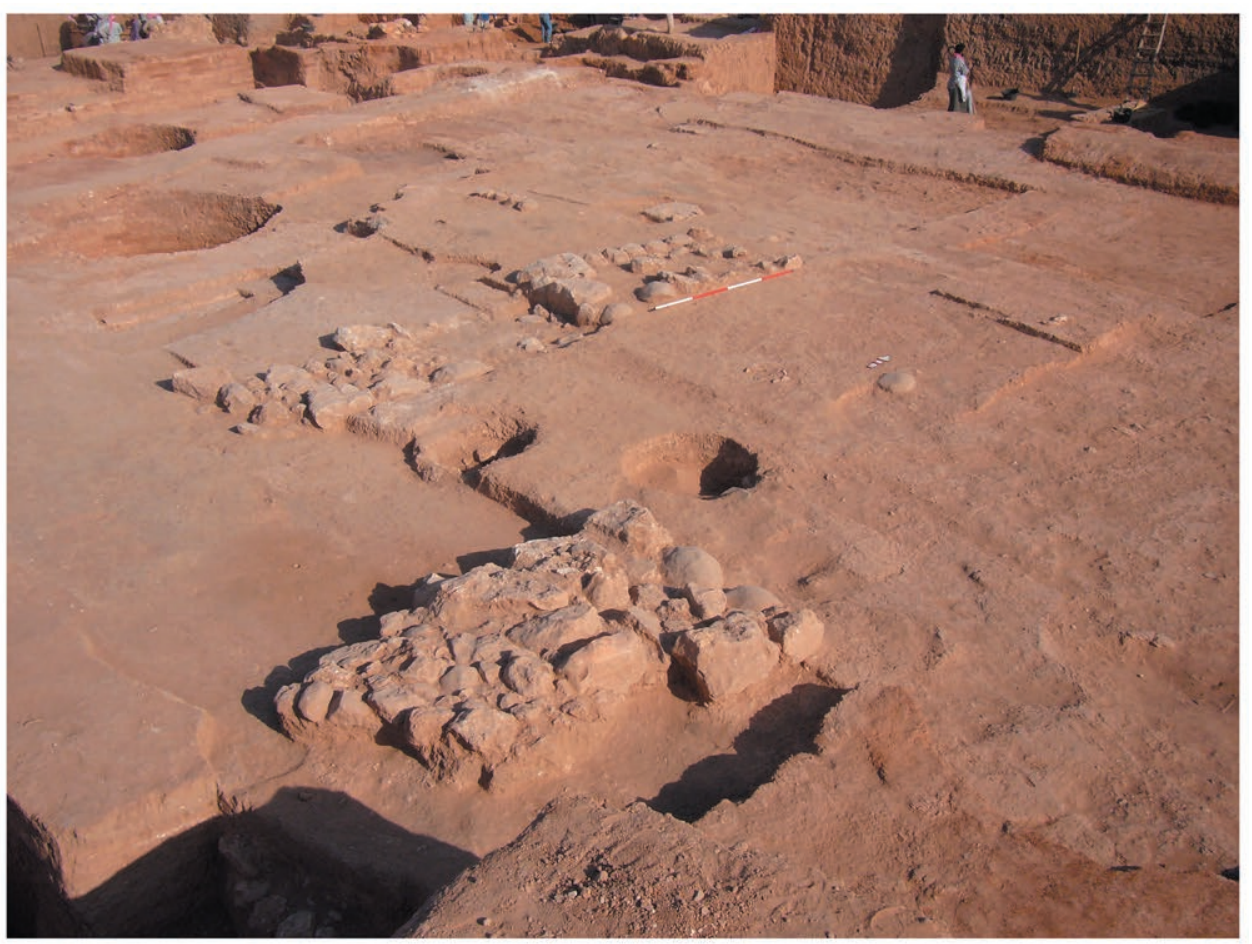

a

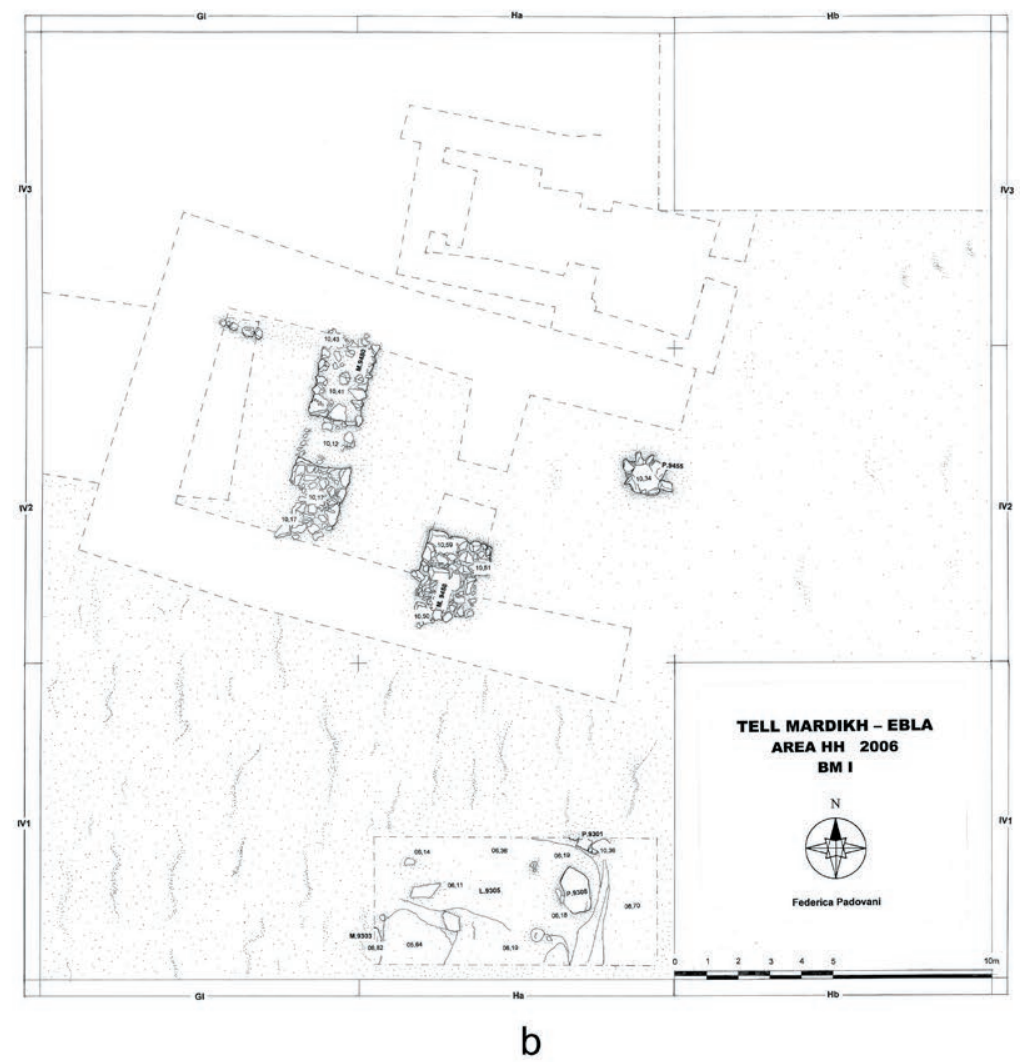

Fig. 9: Ebla, the remains of Temple HH3 of Middle Bronze I in the Lower Town south-east: general view looking north-west (a) and detailed plan (b) with the dashed lines tracing the contours of Temple HH 4 and Temple HH 5 (๑ Missione Archeologica Italiana in Siria). 

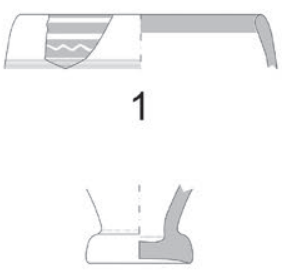

2

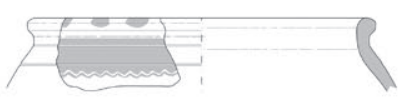

3

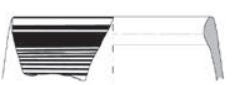

10

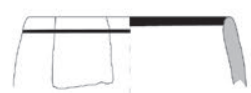

11

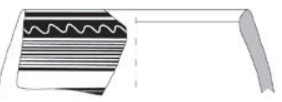

12

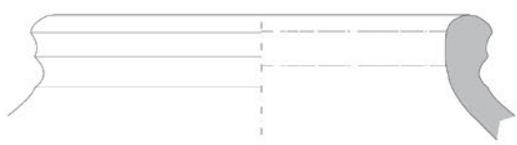

18

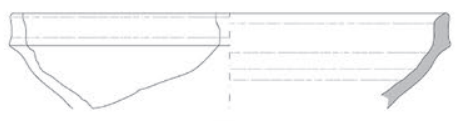

4

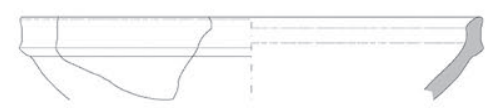

5

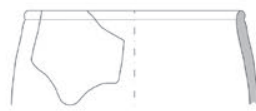

6

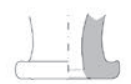

13

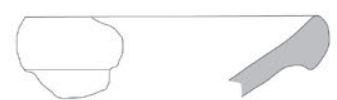

14

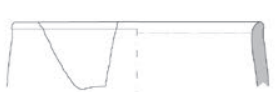

15

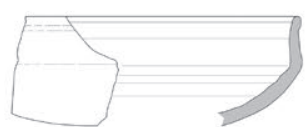

8

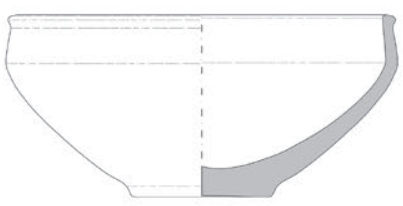

9

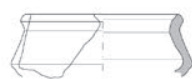

16

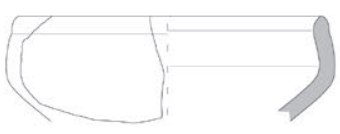

17

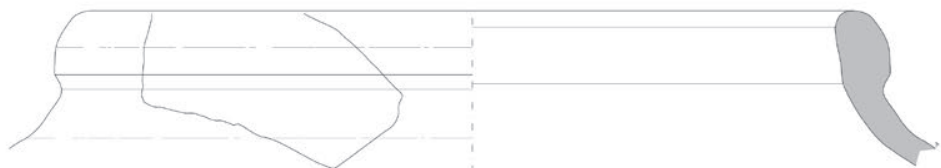

19

22

21

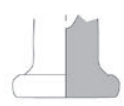

20
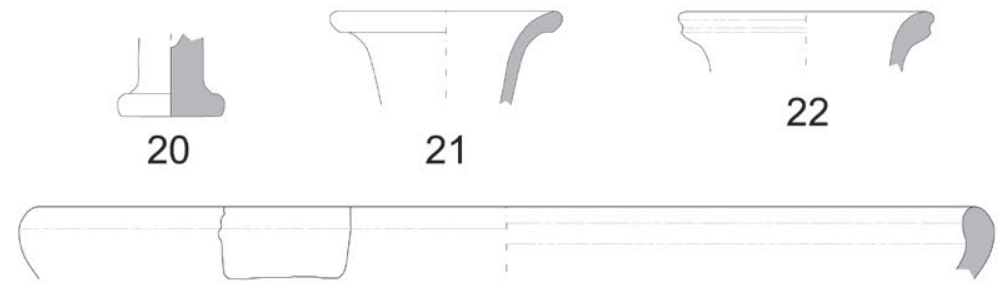

23

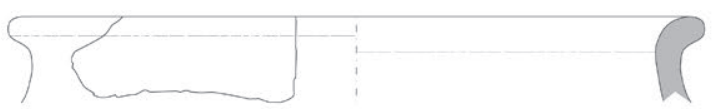

24

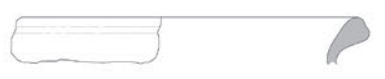

25

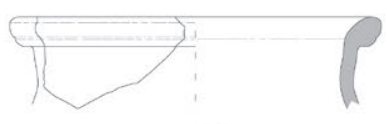

26

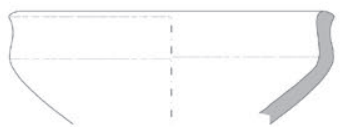

27

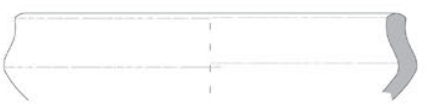

28

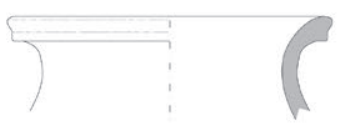

29

Fig. 10: Ebla, late Early Bronze IVB (EB IVB3) pottery from Temples HH4 (1-9), from Area T (10-21), and from Temple D3 in Area D (22-29) (C Missione Archeologica Italiana in Siria). 

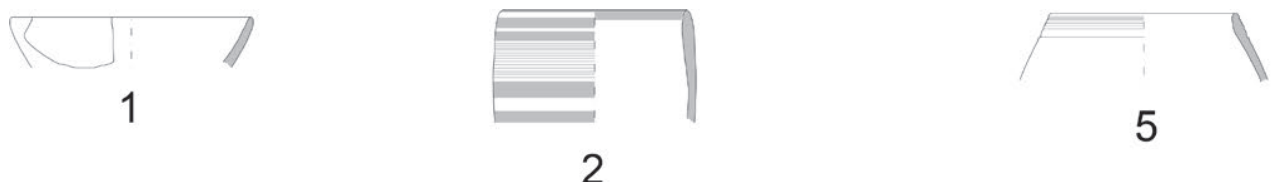

5
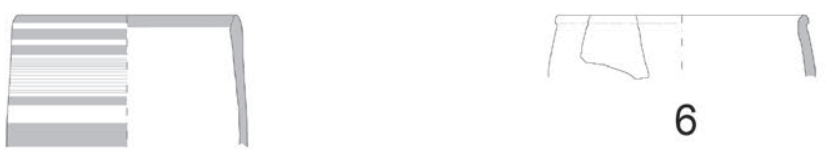

6
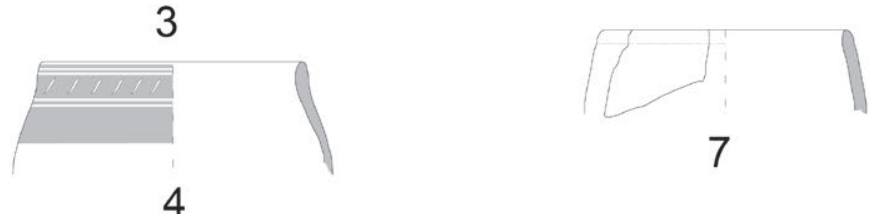

4

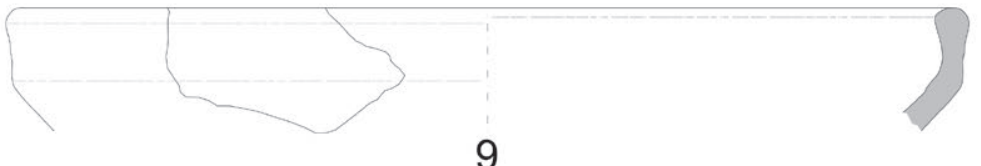

9

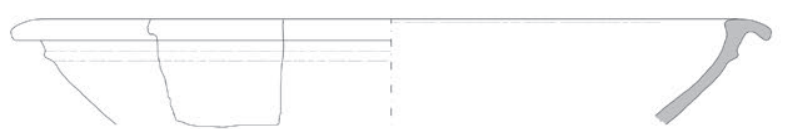

10

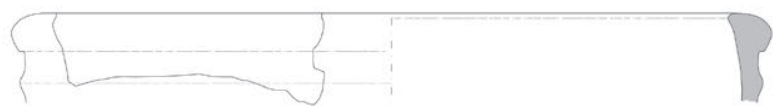

11

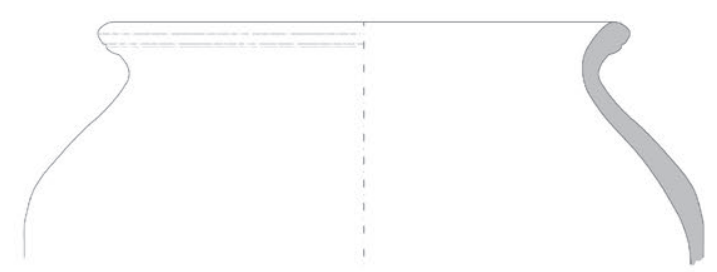

15

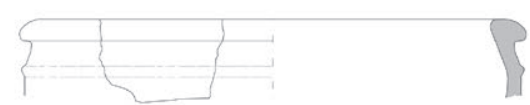

12

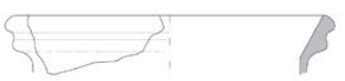

13

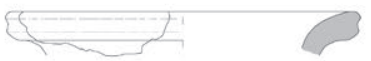

14

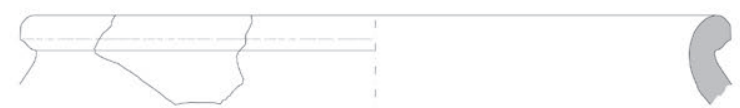

16
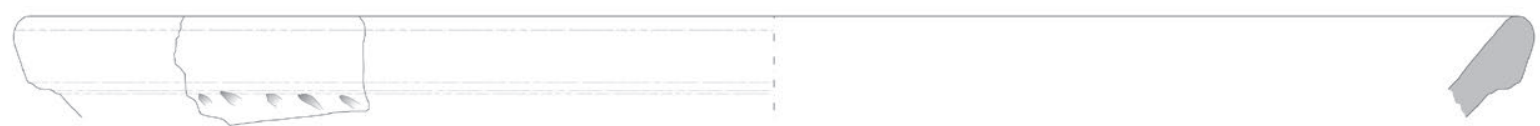

17

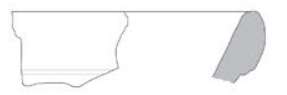

18

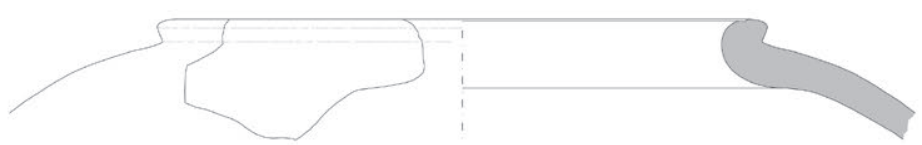

19

Fig. 11: Ebla, terminal EB IVB pottery (EB IVB 4) from Area HH (ㄷ Missione Archeologica Italiana in Siria). 


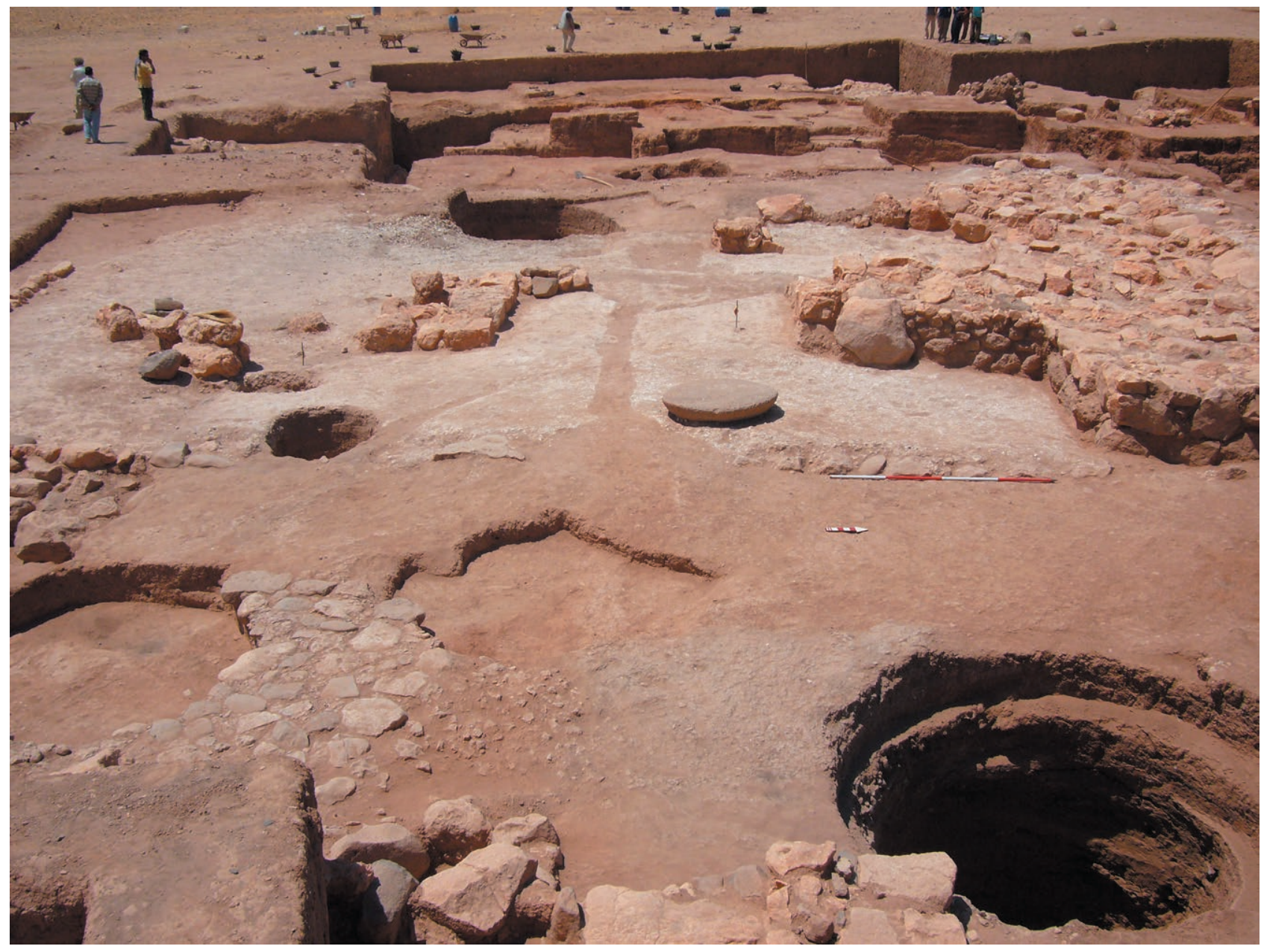

Fig. 12: Ebla, the remains of Temple HH2 of Middle Bronze I-II in the Lower Town south-east, looking west-south-west; the white layer of plaster used as a foundation for the temple cover the remains of the earlier Temple HH3 (@) Missione Archeologica Italiana in Siria). 


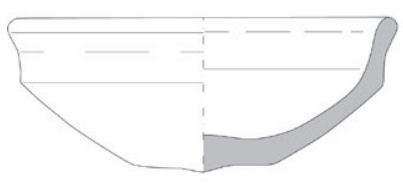

1

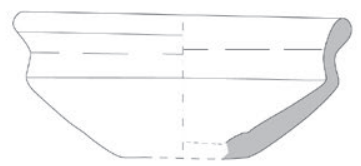

2
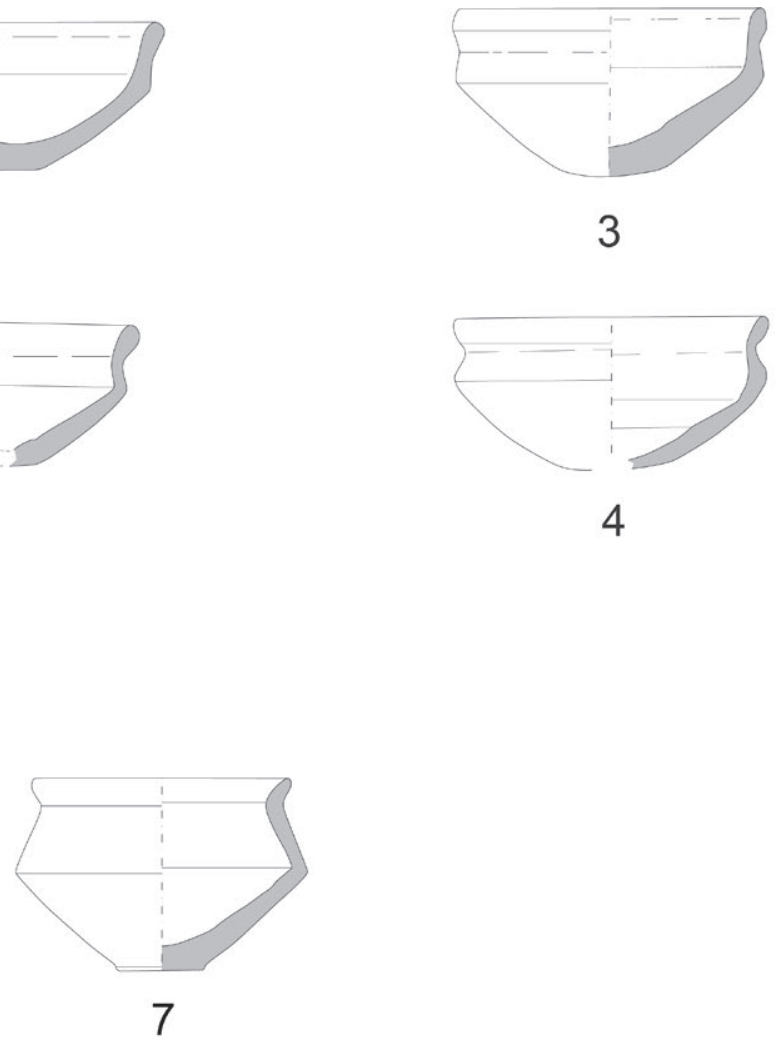

3

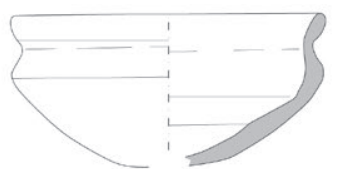

4

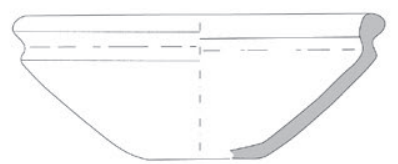

8

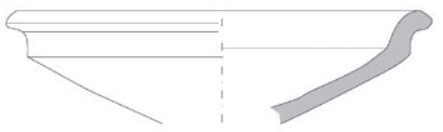

9

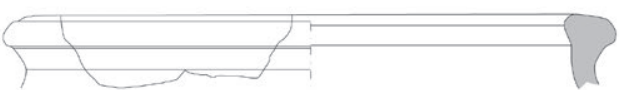

10

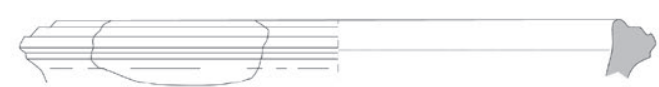

11
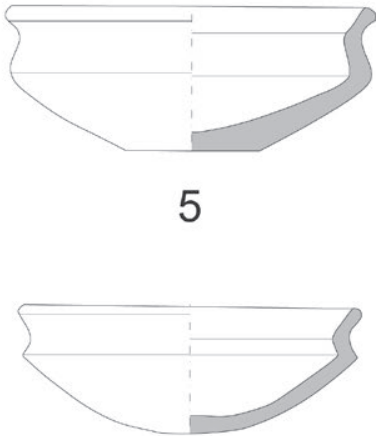

6

Fig. 13: Ebla, Middle Bronze I pottery from the Archaic Palace, Phase II (after Matthiae 2006a) (c) Missione Archeologica Italiana in Siria). 


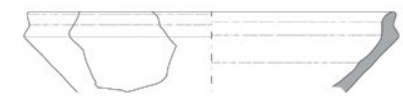

1

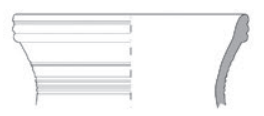

2

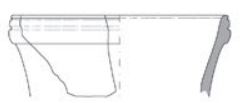

3
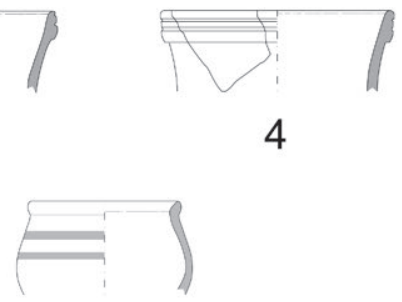

5

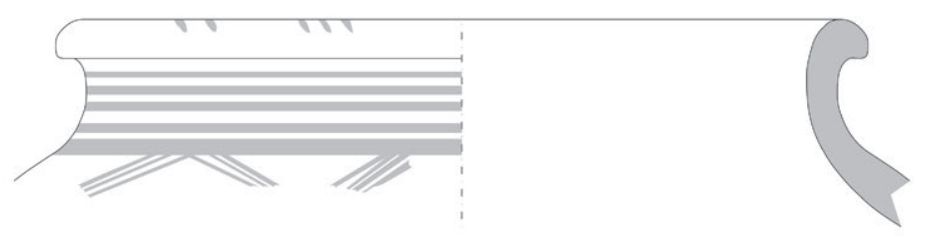

6

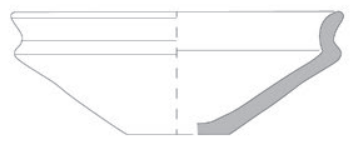

7
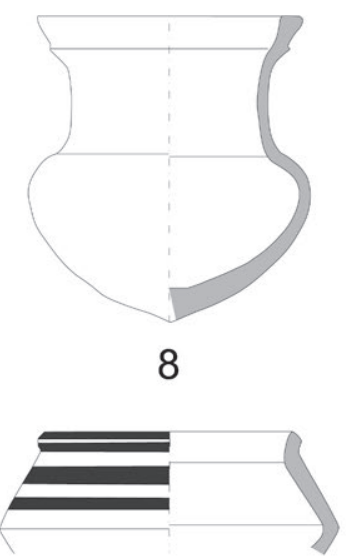

9

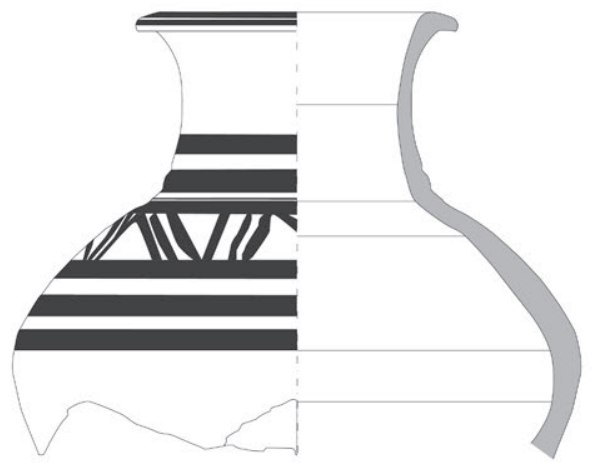

10

Fig. 14: Ebla, Early Bronze IVB carinated cup (1), triple-grooved rimmed jars (2-4), and painted vessels (5-6) from Ebla ( Missione Archeologica Italiana in Siria), and vessels from Phase C7 of Tell Mozan (7-10, after Pfälzner 2017, figs 7.1: K 231, K 480, 7.5: K1141, K 1144). 


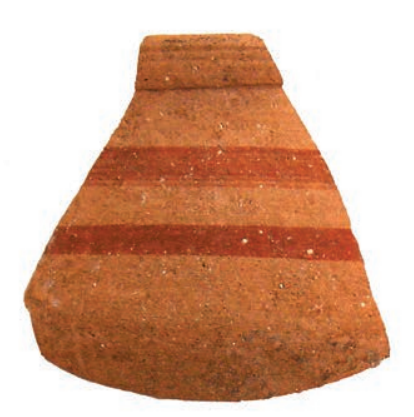

1. TM.07.HH.392/14

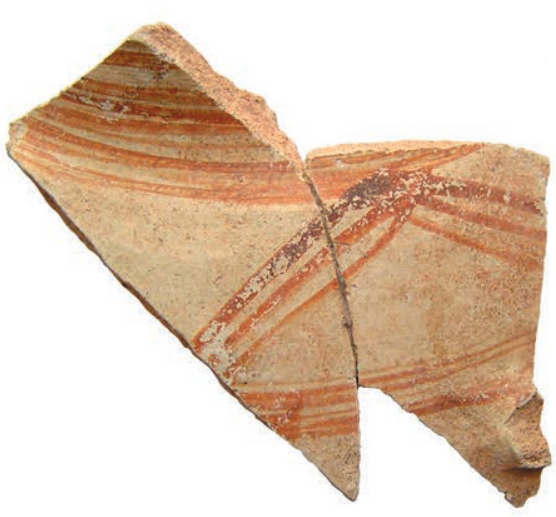

2. TM.06.HH.391/5

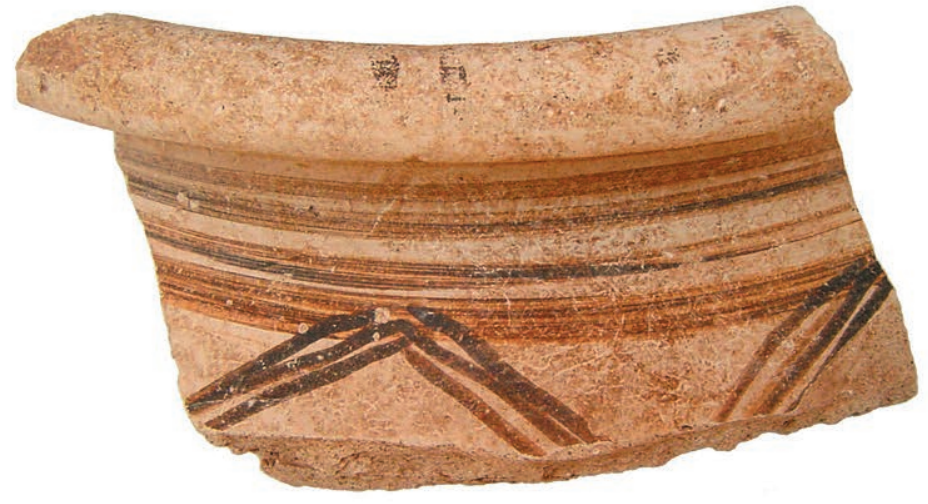

3. TM.06.HH.661/5

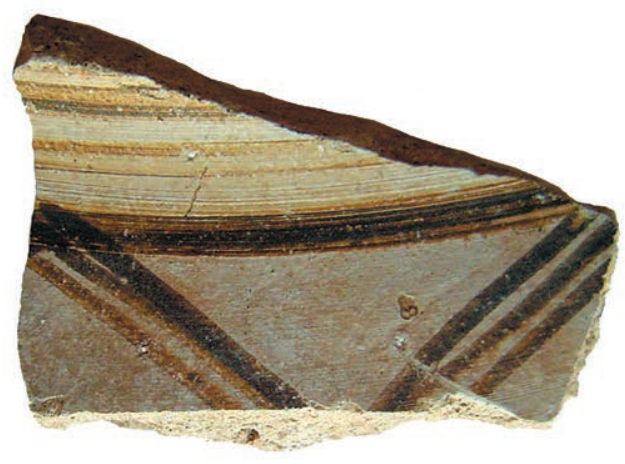

4. TM.07.HН.325/31

Fig. 15: Ebla, Early Bronze IVB painted sherds ( Missione Archeologica Italiana in Siria). 
Ebla between the Early and Middle Bronze Ages: A Précis (and Some New Data)

Tab I: Suggested periodization and stratigraphic correlations between areas with EB IVB occupation at Ebla, also highlighting EB IVB/MB I continuity or discontinuity; edited after D’Andrea 2020a: tab. 1.

\begin{tabular}{|c|c|c|c|c|c|c|}
\hline \multirow{2}{*}{$\begin{array}{l}\text { Archaeological } \\
\text { periodization }\end{array}$} & \multirow[b]{2}{*}{ Phases } & \multicolumn{2}{|r|}{ Area $\mathrm{HH}$} & \multirow[b]{2}{*}{ Area D } & \multirow[b]{2}{*}{ Area T } & \multirow[b]{2}{*}{ Area Z } \\
\hline & & $\begin{array}{c}\text { Local } \\
\text { sequence }\end{array}$ & Activities & & & \\
\hline \multirow{6}{*}{ Mardikh IIB2 } & EB IVB1 & Phase IIa & $\begin{array}{l}\text { Ritual sealing of } \\
\text { Temple of the Rock }\end{array}$ & -.---- & -..--.- & --.---. \\
\hline & & Phase IIb & Houses & & & \\
\hline & EB IVB2 & Phase IIc & $\begin{array}{l}\text { Levelling and } \\
\text { constructional fills }\end{array}$ & ------- & ------- & ------- \\
\hline & EB IVB3 & Phase IId & $\begin{array}{l}\text { Temple HH4, Temple } \\
\text { HH5 }\end{array}$ & Temple D3 & Houses & $\begin{array}{l}\text { Beginning of rampart construction } \& \\
\text { earlier tombs in the rampart } \\
(\mathrm{D} .6707, \mathrm{D} .6709)\end{array}$ \\
\hline & \multicolumn{6}{|c|}{ DESTRUCTION } \\
\hline & EB IVB4 & Phase IIe & Houses & ------ & -.---- & ------ \\
\hline Mardikh IIIA1 & MB I & Phase IIIa & Temple HH3 & $\begin{array}{l}\text { Temple of Ishtar } \\
\text { (D1) }\end{array}$ & Tombs & $\begin{array}{c}\text { Completion of rampart construction } \& \\
\text { later tombs in the rampart }\end{array}$ \\
\hline
\end{tabular}

Tab. II: Suggested correlations between Ebla, Tell Afis and Tell Mishrifeh/Qaṭna discussed in the text; reprised after D’Andrea 2020a: tab. 2.

\begin{tabular}{lccc}
\hline Tell Mardikh/Ebla & & Tell Afis & $\begin{array}{c}\text { Tell Mishrifeh/ } \\
\text { Qatna }\end{array}$ \\
\hline & EB IVB1 & ------ & Phases 26-21 \\
& EB IVB2 &.----- & $\downarrow$ \\
Mardikh IIB2 & EB IVB3 & Afis IV & $\downarrow$ \\
& EB IVB4 & & $\downarrow$ \\
& & Afis IV -V & Phases 20-18 \\
Early Mardikh IIIA1 & MB IA & Until Afis V & Phase 17 \\
& & & $\downarrow$ \\
\hline
\end{tabular}

